\title{
EXCEPTIONAL PATTERNS OF OBJECT MARKING IN BANTU
}

\author{
Michael R. Marlo \\ University of Missouri
}

\begin{abstract}
This article discusses three main phenomena in the morpho-syntax and morphophonology of Bantu languages in which the 1sG object prefix (OP) and/or the reflexive, display anomalous properties compared to other OPs. (i) The 1SG OP and the reflexive commonly have unique combinatorial properties with additional OPs. (ii) The 1sG OP (or, rarely, the reflexive as well) triggers different patterns of final vowel (FV) allomorphy in the imperative. (iii) The 1SG OP but usually not the reflexive behave differently in reduplication. Each of these phenomena is the subject of a micro-typological survey within Bantu, the results of which support the conclusion that morpho-syntactic and morpho-phonological factors are responsible for the full range of anomalous patterns of the 1SG OP and reflexive across Bantu. The exceptional abilities of the 1SG OP and reflexive OP to combine with an extra OP and to trigger a different pattern of FV allomorphy in the imperative are the result of a distinct, lower structural position of the 1SG and reflexive prefixes compared to other OPs, but the overcopying of the 1SG OP in reduplication has a phonological basis.
\end{abstract}

\section{Introduction}

In a wide range of Bantu languages and phenomena, the 1SG object prefix (OP) and the reflexive display exceptional properties compared to other OPs. This paper deals primarily with three phenomena that involve exceptional behavior of one or both of these prefixes: combinations of OPs, allomorphy of the final vowel in the imperative, and reduplication.

Many Bantu languages restrict the number of OPs to just one or two (Bearth 2003: 124-125, Marlo (to appear), Marten \& Kula 2012, Marten et al. 2007). However, the 1SG OP, reconstructed to Proto-Bantu as $*_{\grave{n}}$ - (Meeussen 1967: 98, Polak 1986: 373-374), and the reflexive OP, reconstructed as $*_{i-}$ (Polak 1983), can often co-occur with another OP, even when other OPs cannot cooccur Marlo (to appear), Polak 1986: 403). As shown by the Nyaturu examples in (1a), ${ }^{1}$ combinations of two OPs, which generally have a CV- shape, are disallowed in Nyaturu. However, a second OP may co-occur with $1 \mathrm{SG} N$-, as in (1b), and with reflexive $i-$, as in (1c). ${ }^{2}$

1 In the data provided here, I generally use the transcription of the original source, with occasional translations to the IPA (e.g. using [ $\left.{ }^{\downarrow}\right]$ to mark downstep).

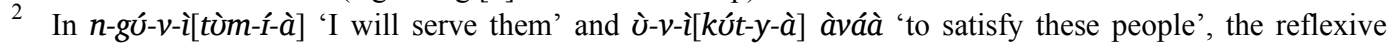
appears to be lexicalized with the verb stem; the reflexive meaning is more transparent in à-mw-ì [ràfì̀y-à] 'he has sworn himself to him'. See Marlo (2014) and Polak (1983) for additional information on the lexicalization of the reflexive. 
(1) Combinations of OPs in Nyaturu (Hualde 1989: 183-185, Olson 1964, Polak 1986, Schlindwein 1986)

a. Two CV- object prefixes

*w-a-va-kv[tom-I-aa]

3SG-PST-3PL-2SG[send-APPL-FV]

'He sent them to you.'

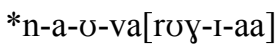

1SG-PST-14-3PL[cook-APPL-FV]

'I cooked it ${ }_{14}$ for them.'

*ù-kì-mò[pá-à]

INF-7-3sG[give-FV]

'to give $\mathrm{it}_{7}$ to him'

b. CV- object prefix $+1 \mathrm{SG} N^{-}$

w-a- - -n[d $0 \gamma-\mathrm{I}-\mathrm{aa}]$

3SG-PST-14-1SG[cook-APPL-FV]

'He cooked it ${ }_{14}$ for me.'

w-a-va-n[tom-I-aa]

3SG-PST-3PL-1SG[send-APPL-FV]

'He sent them to me.'

w-Ú-jdz[àrùm-è] òtàkò

2SG-14-1SG[lend-Fv] 14.bow

'You should lend me your bow.'

c. CV- object prefix + reflexive $i-$

à-mw-ì[ràfì̀y-à]

3SG-3SG-REFL[swear-FV]

'He has sworn himself to him.' *ù-vá-mú ${ }^{\downarrow}$ [tóm-í-à]

INF-3PL-3SG[send-APPL-FV]

'to send him to them / him to them'

*n-a-va-v[roy-I-aa]

1SG-PST-3PL-14[cook-APPL-FV]

'I cooked it ${ }_{14}$ for them.'

ঠ̀-kì-m[pá-à]

INF-7-1SG[give-FV]

'to give $\mathrm{it}_{7}$ to $\mathrm{me}$ '

¿̀-vá-n[tớm-í-à]

INF-3PL-1SG[send-APPL-FV]

'to send them to me / me to them'

ní-w-á-rì-m[p-èè]

FOC-2SG-PST-5-1SG[give-FV]

'the one ${ }_{5}$ you gave to me'

n-gú-v-ì[tòm-í-à]

1SG-FUT-3PL-REFL[send-APPL-FV]

'I will serve them.' $\begin{array}{ll}\text { Ù-v-ì[kút-y-à] } & \text { àváà } \\ \text { INF-3PL-REFL[be.satiated-CAUS-FV] } & \text { 2.people } \\ \text { 'to satisfy these people' } & \end{array}$ 
A second widespread phenomenon involving exceptional behavior of OPs concerns allomorphy of the final vowel (FV) in affirmative imperative singular constructions. The Nyaturu data in (2) are representative of a wide range of Bantu languages. ${ }^{3}$ In imperatives lacking an OP, as in (2a), the verb ends in the FV $-a$, even when there is an object NP, as in (2b). As shown by the forms in (2cd), most OPs, including the reflexive, generally trigger a change in the FV to -e. However, with the $1 \mathrm{SG} \mathrm{N-}$, the verb takes the FV $-a$, as though there is no OP. As shown in (2f), the FV is $-e$ when imperative forms take two OPs, one of which is $1 \mathrm{SG} N-$,

(2) Imperative FV allomorphy in Nyaturu (Olson 1964: 178-180, Schadeberg 1979, Yukawa 1989d: 473-474)

a. Bare verb

\begin{tabular}{|c|c|c|c|}
\hline [1-à] & 'Eat!' & [sútf-à] & 'Return!' \\
\hline [rá-à] & 'Sleep!' & [dèk-á] & ‘Leave!' \\
\hline [tưm-á] & ‘Send!' & [kènk-à] & 'Carry!' \\
\hline [tèyèèy-à] & 'Listen!' & 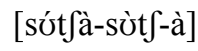 & 'Return quickly!' \\
\hline [tưmá-tứm-á] & 'Keep sending!' & & \\
\hline
\end{tabular}

b. Bare verb + NP object

$\begin{array}{ll}\text { [yờ-á] yòmbè } & \text { 'Buy a cow!' } \\ \text { [tàf-á] màdzì } & \text { 'Fetch water!' } \\ \text { [háy-ì-à] màbòvà } & \text { 'Dislodge stalks!' }\end{array}$

c. $\mathrm{Verb}+\mathrm{OP}$

mò̀yàndz-è] 'Love him!' rì[hémbèk-è] 'Transplant it 5 !'

d. Verb + Reflexive

$\mathrm{i}[\mathrm{d}$ zur- $\varepsilon] \quad$ 'Shave yourself!' i[on- $\varepsilon] \quad$ 'See yourself!'

3 Examples (2d) and (2f) are from my notes with Aaron Mbogho, a speaker of Ghirwana Nyaturu, with whom I was able to work for only a few hours on object marking phenomena. Aaron's patterns of object marking differ in a number of respects from what is reported for Nyaturu in the literature. Aaron allowed the relatively free combination of $1 \mathrm{sg} N$ - with a second OP and also allowed two CV- OPs in limited other contexts, e.g. Yohana $w$ - $a$-va-rr $[r u g h-i \varepsilon]$ 'Yohana cooked it ${ }_{5}$ for them'. No examples were identified in which the reflexive grammatically combines with a second OP, and Hualde's (1989) generalizations that definite animate NPs are obligatorily doubled by an OP and that inanimate NPs cannot be doubled do not characterize this variety. The present examples also appear to have phonetic differences compared to what is transcribed elsewhere (e.g. in the vowel of the applicative), though this may be an artifact of my brief encounter with the speaker and language. I have not attempted to harmonize my transcriptions with those of other descriptions of Nyaturu. 
e. Verb $+1 \mathrm{SG}$ OP

\begin{tabular}{|c|c|c|c|c|}
\hline y[òng-à] & (/-hòng-/) & 'Follow me!' & $\mathrm{m}\left[\right.$ bút $\left.\int-a ̀\right]$ & 'Awaken me!' \\
\hline n[úmb-á] & (/-úmb-/) & 'Create me!' & $\mathrm{n}$ [dét-è-à] & 'Bring to me!' \\
\hline n[ón-á] & (/-ón-/) & 'See me!' & $\mathrm{n}[\mathrm{s} u ́ t$ t-à] & 'Return me!' \\
\hline $\mathrm{n}[\mathrm{d}$ z-òr-à $]$ & (/-òr-/) & 'Draw me!' & n[tó-à] & 'Send me!' \\
\hline y[xán-Ì-à] & & 'Speak to me!' & & \\
\hline \multicolumn{5}{|c|}{ Verb $+\mathrm{OP}+1 \mathrm{sG} \mathrm{OP}$} \\
\hline mo-n[dzur & $-\varepsilon y-\varepsilon]$ & 'Shave him for me!' & & \\
\hline va-n[dzur- & $\varepsilon y-\varepsilon]$ & 'Shave them for me!' & & \\
\hline
\end{tabular}

As discussed in $\S 4$, reflexive $i$ - rarely behaves like the 1SG OP, triggering the $-a$ allomorph.

A third phenomenon with exceptional behavior of OPs is verbal reduplication. As shown in (3a-b), CV-shaped prefixes, including OPs, are not copied in the reduplicated forms of C-initial verb stems in Hehe. However, as shown in (3c), the $1 \mathrm{SG}$ OP $n$ - appears in both halves of reduplicated stems.

(3) Overcopying of the $1 \mathrm{SG}$ OP $n$-in Hehe (Odden \& Odden 1985)

a. No OP

kú[ceengela][ceeng-él-a] tu[gulite][gúl-ite]

INF[RED][build-APPL-FV] 1PL[RED][buy-FV]

'to build for a bit' 'We shopped a bit.'

b. CV-OP

kú-fi[gula][gúl-a]

INF-8[RED][buy-FV]

'to buy a bit of them 8 '

c. $1 \mathrm{SG}$ OP $\mathrm{n}^{-}$

va-kúu-n[doongaa][n-doóng-a]

3PL-PRES-1SG[RED][1SG-nag-FV]

'They nag me.' (/-loong-/ 'nag')

As discussed further in $§ 5$, the reflexive generally does not overcopy in reduplication, differing in this respect from the $1 \mathrm{SG}$ OP.

There are several possible factors that could be responsible for the divergent behavior of the 1SG and reflexive prefixes compared to other OPs, as these morphemes often differ from other OPs in several ways. Three commonly distinctive properties of these morphemes are listed in (4). 
(4) Unique properties of the $1 \mathrm{SG}$ and reflexive Ops

a. The $1 \mathrm{SG}$ OP and the reflexive are generally required to surface closest to the verb stem (Polak 1983: 297) and may therefore be in different morphological or syntactic positions from other OPs (Buell 2005, Muriungi 2008).

b. 1SG and reflexive are highest on animacy-topicality and person-number hierarchies, which are known to play a role in object marking (Alsina 1994, Contini-Morava 1983, Duranti 1979, Rugemalira 1993).

c. Most OPs have a CV-shape, but $1 \mathrm{SG}$ and reflexive are generally unique in having monophone $\mathrm{N}$ - and $\mathrm{V}$-.

These diverse properties suggest two general types of analyses to account for the exceptional behavior of the 1SG and reflexive OPs: morpho-syntactic accounts, building on properties (4a-b), and morpho-phonological accounts, building on property $(4 \mathrm{c})$. After reviewing the microtypological patterns of OP combinations, final vowel allomorphy, and reduplication across a widerange of Bantu data, I show in this paper that both types of analyses are necessary to account for the full range of data. In $\S 3$ and $\S 4$, I argue that the exceptional patterns of OP combinations and the FV allomorphy triggered by the 1 SG and reflexive markers are the result of a distinct morphosyntactic position of the $1 \mathrm{SG}$ and reflexive prefixes, lower than other OPs, as proposed for individual Bantu languages by Buell (2005), Muriungi (2008), and Sikuku (2012). In §5, I show that the overcopying of the 1SG OP and other prefixes in Bantu reduplication has a morpho-phonological account, following work such as Downing (1998b).

The finding that both morpho-syntactic and morpho-phonological analyses are required to account for different exceptional behavior of the 1SG and/or reflexive OPs confirms and extends previous results. Most prior research in this area has focused on only a subset of the phenomena dealt with here, usually inspecting only a single language at a time, and has proposed either syntactic or phonological analyses. This paper builds on prior work in establishing a broad database of facts which draws on a large set of languages and phenomena to help clarify the relative role of morpho-syntactic and morpho-phonological factors in the exceptional behavior of OPs. The micro-typologies established here and in Marlo (to appear) advance research aiming to articulate patterns of variation among Bantu languages in object marking (e.g. Beaudoin-Lietz et al. 2004, Marten \& Kula 2012, Marten et al. 2007, Polak 1986).

Before proceeding to the detailed discussion of each phenomenon, some background information on the structure and phonology of the Bantu verb is provided in $\S 2$, which elaborates on and contextualizes the unique properties of the 1SG OP and the reflexive listed in (4) above.

\section{Background on OPs and Bantu verb structure}

A widely adopted representation of Bantu verb structure, which ignores clitics, is provided in (5). The 'stem' includes an obligatory verb root, one or more possibly occurring derivational suffixes called 'extensions', and the 'final vowel' suffix, which is required in most Bantu languages outside the northwest.

The stem is the minimal verbal structure that can be pronounced independently in imperative forms, and "is the unambiguous locus of much ... phonological and prosodic activity in Bantu" 
(Hyman 2008: 327). It can be subject to minimality requirements and is often the domain for reduplication, tonal processes, vowel harmony, consonant and vowel distributional restrictions, and nasal consonant harmony (Downing 1999c, 2001, Hyman 1993: 25, 2008, Myers 1998). See Mchombo (2004) for other arguments for the stem as a constituent.

Hierarchical morphological representation of the Bantu verb (adapted from Downing 2003, Hyman 2008:325, Hyman et al. 2008)

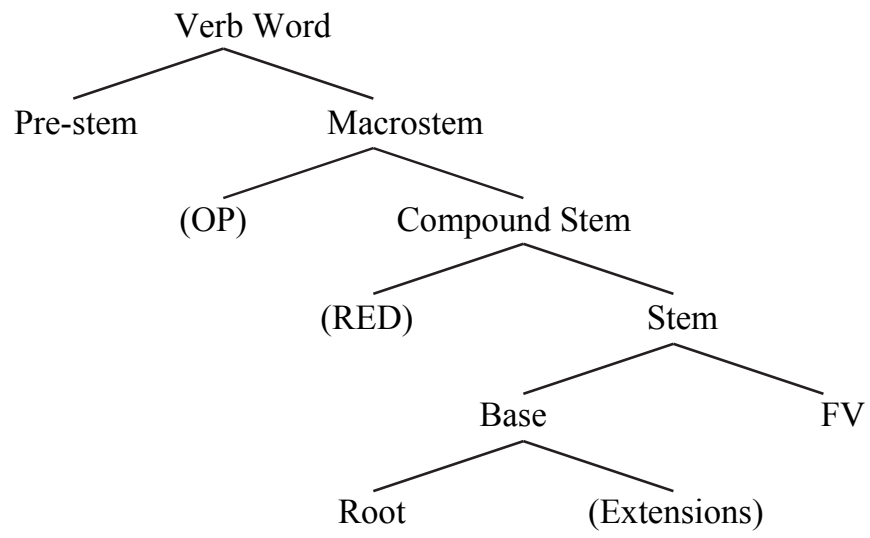

Following Downing (2003), the reduplicated verb is represented here as a compound structure, the 'compound stem', composed of two stems. The reduplicant generally precedes the base and is often required to be minimally and maximally two syllables in size.

The 'macrostem' includes the reduplicated stem and preceding OPs. Depending on the language and analysis, the OPs are sometimes considered affixes ('infixes' or 'prefixes'), clitics, pronouns, or agreement markers (or 'concords'; see Adams 2010, Baker 2008, Bax \& Diercks 2012, Bearth 2003, Bresnan \& Mchombo 1987, Buell 2005, Byarushengo et al. 1976, Demuth \& Johnson 1990, Diercks \& Sikuku 2011, Duranti \& Byarushengo 1977, Henderson 2006, Mchombo 2004, Riedel 2009, van der Spuy 1993, Woolford 1999, 2000, 2001, Zeller 2012, Zerbian 2006.) I use 'object prefix' in a theory-neutral way here and use 'object marker' in a more general sense to include both pre-stem and post-stem morphemes indexing objects. See Beaudoin-Lietz et al. (2004) and Marlo (to appear) for more on post-stem object marking.

Some Bantu languages in the northwest have no OPs, and a large number of other Bantu languages are reported to limit the number of OPs to just one. However, there are also many languages that allow multiple OPs, and within those languages there is considerable diversity in the exact number of OPs that are allowed: some languages, such as Nyaturu in (1), allow two OPs only in highly restricted contexts, while others more freely allow two, three, four, up to a maximum of five (Kuria) or even six (Rwanda) OPs (Bearth 2003: 124-125, Kearns 2008, Marlo (to appear), Marten et al. 2007, Marten \& Kula 2012).

Tonal evidence is the primary motivation for a macrostem constituent, as the macrostem commonly serves as the domain of tonal rules, including the assignment of inflectional tonal suffixes ('melodic Hs') in a number of Bantu languages (see Marlo (2013) and references therein). The macrostem sometimes also plays a role in other morpho-phonological phenomena such as vowel harmony (Archangeli \& Pulleyblank 2002, Boyd 2008) and reduplication (Hyman et al. 2008, Sibanda 2004). 
Previous research has only rarely discussed the representation of multiple OPs with respect to the macrostem. Tonal evidence will likely prove crucial in future work in this area, but there is little information available concerning the issue of whether multiple OPs are contained within in a single macrostem tone domain, aligned with the leftmost OP, or whether there is one macrostem tone domain per OP. Yao (Hyman \& Ngunga 1994) is the only Bantu language I am aware of that provides potential evidence for recursive macrostems, though I give an alternative interpretation in Marlo (2014). Kuria is an example of a language in which all OPs are contained within a single prosodic macrostem with respect to tonal assignment rules (Marlo et al. (2014a, b), Mwita 2008, Odden 1987).

The prefixes preceding the OPs comprise a number of different inflectional markers, including subject prefixes (SPs) and tense-aspect and negation prefixes. In at least some languages, there is evidence that the pre-stem prefixes form their own independent prosodic domain (Barrett-Keach 1980, 1986, Hyman 1987, Myers 1990, 1998).

Research in Bantu syntax has proposed derivations and representations that are largely compatible with the structure in (5) (see e.g. Buell 2005, Julien 2002: 195-196, Muriungi 2008, and Myers 1990: 116). For example, under Buell's (2005) approach, most of the morphological constituents have corresponding syntactic constituents: Base $=$ VP, Stem $=$ AuxP, Macrostem $=$ AgrOP, Verb Word = AgrSP. However, the pre-stem domain does not readily translate to a syntactic constituent in this approach (see Myers 1998). The compound stem is not discussed in Buell (2005), but see Muriungi (2008: 107-110) for discussion of reduplication in the context of Tharaka syntax.

The following subsections elaborate on the morpho-syntactic positions of the 1SG OP and the reflexive in $\S 2.1$ and on the phonological properties of these prefixes in $§ 2.2$.

2.1 The order of OPs. In languages that allow more than one OP, the 1SG and reflexive prefixes are often required to surface finally, in a position linearly adjacent to the stem (Polak 1983: 297). Meeussen (1967: 110) reconstructs the reflexive for Proto-Bantu as being the innermost OP, and Polak (1983: 297) describes the reflexive as "intimately tied to" and sometimes inseparable from the verb root. The reflexive is often assumed to be one of the OPs (Harjula 2004: 127, Mchombo 1993, Meeussen 1967), but the position of the reflexive immediately preceding the stem and following other OPs is one piece of evidence that has been given in a few works that have argued that the reflexive is distinct from the OPs (Buell 2005, Muriungi 2008, Sikuku 2012).

In a handful of languages, including Kwanyama (Halme 2004: 74-75), Wambo languages such as Ndonga (Fivaz 1986: 104-105, Polak 1986: 375), and Kwangali (Dammann 1957: 21), the 1SG object marker is an enclitic while other (non-locative) object markers are OPs. This fact is relevant for the discussion of patterns of FV allomorphy in the imperative in $\S 4$.

Buell (2005: 41) states that the reflexive always "immediately precedes the stem, regardless of which argument it saturates". However, one context where we find variation across Bantu in the order of the reflexive with respect to other OPs, is with the 1SG OP, counterexemplifying Buell's generalization. It is indeed the case that the reflexive follows the 1SG OP in languages such as Bukusu, Kerewe (David Odden, p.c.), Nyala-West (Ebarb et al. in prep), Wanga (Marlo field notes), and Rundi, as shown in (6). 
(6) 1sG-reflexive order

a. Bukusu (Jastino Sikuku, p.c.)

Wekesa a-a-nj-i[siim-isy-a]

Wekesa 3sG-PST-1SG-REFL[like-CAUS-FV]

'Wekesa made me like myself.'

b. Rundi (Juvenal Ndayiragije, p.c.)

a-á-ra-n-i[heb-ir-ye]

3SG-TNS-DISJ-1SG-REFL[abandon-APPL-FV]

'He sacrificed himself for me.'

However, as shown in (7), this order is not found in Kikuyu ${ }^{4}$, Tharaka, or Tswana, as the reflexive precedes the $1 \mathrm{SG}$ OP in these languages.

(7) Reflexive-1SG order

a. Kikuyu (Barlow 1951: 122)

w-ĩ̃-n[garũr-ĩr-e]

2SG-REFL-1SG[turn-APPL-FV]

'Turn (yourself) toward me.'

b. Tharaka (Muriungi 2008: 122)

a-gû-î-n[kum-îr-i-a]

3SG-TNS-REFL-1SG[be.proud-APPL-CAUS-FV]

'S/he has been proud to the detriment of me.'

c. Tswana (Cole 1955: 234, cf. Chebanne 1992)

go-i-m[pola-cl-a]

INF-REFL-1sG[kill-APPL-FV]

'to kill himself for me'

Muriungi (2008: 121-122) takes the reflexive-1SG order in Tharaka as evidence that the 1SG OP occupies a lower structural position than the reflexive, which itself is lower than other OPs, yielding an analysis that I adapt in (8).

4 In Kikuyu and Tharaka orthography, the 2nd degree vowels [e o] are represented with a high vowel plus a diacritic: $<\tilde{1} \tilde{\mathbf{u}}>$ in Kikuyu and $<\hat{\imath} \hat{\mathrm{u}}>$ in Tharaka. 
(8)

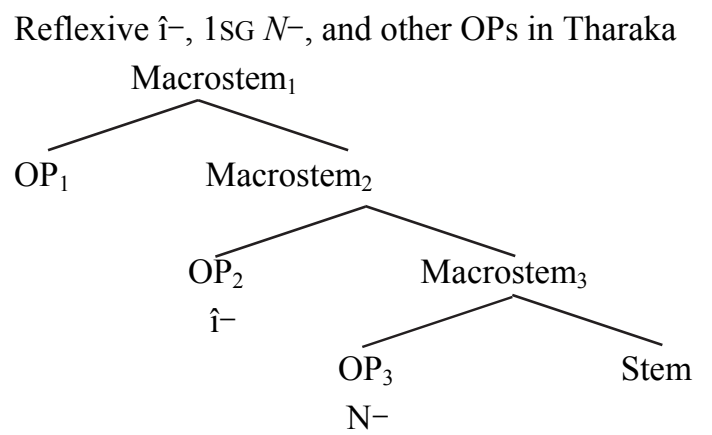

An additional variant is found in Tiriki, in which either order of 1SG and reflexive is possible, without a concomitant change in meaning.

(9) Variable order of reflexive and 1SG OP in Tiriki (Marlo in prep.)
a. à-1-ì́-m[bàlìts-ìr-à]
à-làá-nz-ì[vàlìts-ìr-à]
3SG-FUT-REFL-1SG[count-APPL-FV]
3SG-FUT-1SG-REFL[count-APPL-FV]
'He will count himself for me.'
'He will count himself for me.'
b. à-l-ìí-m[bèk-èr-à]
à-làá-nz-ì[vèk-èr-à]
3SG-FUT-REFL-1SG[shave-APPL-FV]
3SG-FUT-1SG-REFL[shave-APPL-FV]
'He will shave himself for me.'
'He will shave himself for me.'

It has been claimed for some Bantu languages such as Haya, Nyambo, Rwanda, and Sambaa that the inner placement of the 1SG and reflexive prefixes reflects the influence of animacy-topicality and person-number hierarchies on the order of the OPs, as 1SG and reflexive are highest on these hierarchies (Alsina 1994, Contini-Morava 1983, Duranti 1979, Rugemalira 1993). See Bentley (1994), Duranti (1979), Hawkinson \& Hyman (1974), Kidima (1987), Marlo (2012b), Morolong \& Hyman (1977), Riedel (2009), and Woolford (1999, 2000, 2001), among others, for further discussion of the role of person-number and animacy-topicality hierarchies in object marking and agreement in Bantu.

In some languages, the syntactic relation or thematic role determines the order of the OPs, often a mirror image of the order of postverbal NPs (Bearth 2003), as it is in certain varieties of Tswana (Creissels 2002: 391). In Sambaa, for instance, the order of the OPs follows from their grammatical roles, the direct object (theme) being closest to the stem.

(10) IO-DO order of OPs in Sambaa (Riedel 2009: 140)
a. a-za-ku-ni[ony-esh-a]
3SG-PERF-2SG-1SG[see-CAUS-FV]
'S/he pointed you out to me.'
b. a-za-ni-ku[ony-esh-a]
3SG-PERF-1SG-2SG[see-CAUS-FV]
'S/he pointed me out to you.'

(10b) shows that the 1SG OP is not always stem-adjacent, as we saw for the reflexive in (7) - (9). Nevertheless, in languages where syntactic relations or thematic roles determine the order of the OPs, there may be overriding ordering requirements on the $1 \mathrm{SG}$ and reflexive prefixes. In Ruri, the OP indexing the indirect object (beneficiary) normally precedes the OP indexing the direct object 
(theme), as in Sambaa. However, according to Massamba (1982: 52), the 1SG OP must always appear closest to the stem, irrespective of its grammatical role.

Following Buell (2005), Muriungi (2008), and Sikuku (2012), it is argued below that the inner placement of the 1SG OP and the reflexive is responsible for the special ability to license an additional OP and to trigger anomalous patterns of FV allomorphy in the imperative. However, other OP anomalies often involving the 1SG OP, including the overcopying in reduplication, are the result of phonological properties of the prefixes, which are the focus of the next subsection.

2.2 Phonological properties of OPs. Prefixes generally have a CV- shape in Bantu verbs.

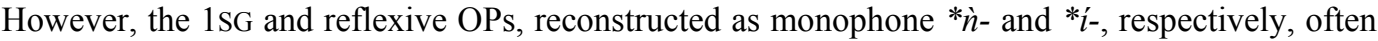
diverge from the canonical CV- shape of OPs. ${ }^{5}$ The inventory of OPs of Nyaturu in (11) is representative for many Bantu languages in terms of the usual prosodic shape of the prefixes: all OPs are CV-except $1 \mathrm{SG} N$ - and reflexive $i$-.

(11) OPs of Nyaturu (Olson 1964, Schadeberg 1979)

\begin{tabular}{|c|c|c|}
\hline $1 \mathrm{SG}$ & N- & 1PL \\
\hline $2 \mathrm{SG}$ & qù- & $2 \mathrm{PL}$ \\
\hline $3 \mathrm{SG}$ & mù- & $3 \mathrm{PL}$ \\
\hline cl. 3 & wú- & cl. 4 \\
\hline cl. 5 & rí- & cl. 6 \\
\hline cl. 7 & qÍ- & cl. 8 \\
\hline cl. 9 & wú- & cl. 10 \\
\hline cl. 11 & wú- & cl. 12 \\
\hline cl. 15 & qù- & cl. 14 \\
\hline
\end{tabular}

In addition to the fact that the $1 \mathrm{SG}$ prefix is commonly just a single segment (or sometimes even smaller, i.e., a nasal feature), there are at least two additional distinguishing phonological traits of the 1SG OP. First, $1 \mathrm{SG} *{ }^{n}$ - assimilates in place of articulation to the following consonant and triggers a variety of cross-linguistically typical NC effects, such as post-nasal voicing, post-nasal hardening, etc. (Hyman 2001, 2003a, Odden to appear). These effects commonly obscure the boundary between the prefix and root. The data in (12) from Tuki show what Hyman (2008: 342344) refers to as 'prefix+stem fusion', where "properties of the prefix are incorporated into the following root": the $1 \mathrm{SG}$ marker surfaces as nasalization on the voiced stop-initial roots in (12a) but turns the non-continuant stem-initial segments in $(12 b)$ into voiceless stops or affricates, without nasalization.

5 One wonders whether the surface ordering of the OPs may be sensitive to phonological properties. The placement of the monophone $1 \mathrm{sg} * \grave{n}$ - and reflexive ${ }^{*} \hat{-}$ - after other OPs appears to be parallel to the ordering of the single-segment causative and passive suffixes ${ }^{*} i$ and ${ }^{*}-u$ following the VC-shaped extensions within the stem (Hyman 1993). 
(12) 'Prefix-stem fusion' of 1 SG OP in Tuki (Hyman \& Biloa 1992)
a. à-byònò-ḿ
à-dìngà-ḿ
'He follows.'
à-m-byònò-ḿ
'He follows me.'
'He loves.'
à-n-dìngà-ḿ
'He loves me.'
b. à-fá-ḿ 'He gives.' à-pá-ḿ 'He gives me.'
à-sèyà-ḿ 'He abuses.' à-tsèyà-ḿ 'He abuses me.'
à-wúbá-ḿ 'He hits.' à-kúbá-me 'He hits me.'

These kinds of mutations, which are common effects of $1 \mathrm{SG} * \grave{n}-$, render impossible the linear segmentation of the prefix from the stem and raise the possibility that $1 \mathrm{SG} * \dot{n}$ - becomes phonologically incorporated into the verb stem. Other OPs are generally not known to trigger similar effects, though reflexive $i$ - does trigger mutations of the following stem-initial segment in Tswana (Dickens 1984, Mmusi 1992: 34-35).

Under some analyses, the NC sequence that results from the affixation of $1 \mathrm{SG} * \grave{n}$ - is considered to form a single complex ('prenasalized') segment with the stem-initial consonant. In this type of analysis, as well as in some other analyses treating the nasal as part of a cluster, such as those in (13a-b), the nasal prefix differs from other OPs in that it is syllabified with the verb stem (Hubbard 1995, Hyman 1992), an additional factor that favors its phonological parsing with the verb stem. Under Downing's (2005) proposed representation for NCs in (13c), the nasal is syllabified exclusively in the coda of the syllable preceding the stem-initial consonant, so syllabification does not favor parsing nasal prefixes with the following stem. In all analyses, the nasal shares place of articulation features with the stem-initial segment, a further property that generally distinguishes the 1SG OP from other OPs and which phonologically links the 1SG prefix to the stem. ${ }^{6}$

(13) Representations of nasals in Bantu
a. Semi-geminate
b. Onset
c. Uniform
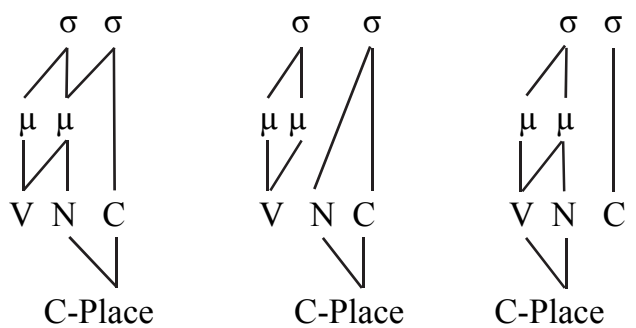

Principles of syllabification do not favor the phonological parsing of reflexive $*_{i \text { - }}$ with the following stem. However, the combination of reflexive $*_{i \text { - }}$ plus a C-initial verb stem can be phonologically indistinguishable from a V-initial stem (Polak 1983: 297), a factor that may explain synchronic anomalies of V-initial stems in some languages (see Marlo 2014).

6 Some Bantu languages have 'syllabic nasal' OPs, especially involving 3sg *mu-. In some languages, the syllabic nasal has an invariant place of articulation, e.g., $m$ - in Swahili and $n$ - in Machame Chaga (Yukawa 1989a). In other languages, such as Mpoto (Zac Branson, p.c.), Mwera (Odden 1999), and Yao (Hyman \& Ngunga 1997), the syllabic nasal assimilates to the place of the following consonant and may also trigger other NC effects. In this paper I generally deal only with the 1sg 'moraic' nasal. 
When verb stems begin with a vowel, any OP can be potentially be syllabified with the initial segment of the stem. As discussed in a series of works by Laura Downing (e.g., Downing 1998a, b, 1999c, 2006, 2009) and in $\S 5$ below, all OPs are treated as stem-initial in such contexts in some languages. Facilitating the surface morphological parse, the $1 \mathrm{SG}$ OP and reflexive show allomorphy in a number of other languages depending on whether the stem begins with a $\mathrm{C}$ or a V: $n$ - before $\mathrm{C}$ and $n i$ - / $n y$ - before $\mathrm{V}$; $i$ - before $\mathrm{C}$ and $i C$ - before V (Polak 1983: 284, 1986: 378-380, 413).

With this background in place, I now turn to further discussion of OP combinations in $\S 3$, allomorphy of the FV in the imperative in $\S 4$, and reduplication in $\S 5$. In each section, I provide a micro-typology of the relevant phenomenon within Bantu languages and discuss possible analyses.

\section{OP combinations}

This section explores in greater depth the generalization that $1 \mathrm{SG} * \grave{n}$ - and reflexive $*_{i-}$ commonly license one OP more than is otherwise allowed. I begin by discussing cases reported in the literature in which the 1SG OP, the reflexive, or both markers exceptionally license an additional $\mathrm{OP}$, and then propose a morpho-syntactic analysis of these facts.

3.1 Micro-typological patterns. In addition to Nyaturu, noted in (1) above, several other Bantu languages, including those in (14), normally allow only a single OP but allow a total of two OPs just in case one is $1 \mathrm{SG} N$ - or reflexive $i$-.

(14) Languages that allow two OPs only with $1 \mathrm{SG} N$ - or reflexive $i$ -

Fuliiru (Van Otterloo 2011: 40-41)

Kamba (Angelina Kioko, p.c.)

Marachi (Marlo 2007)

Nyala-West (Marlo 2007)

Nyaturu (Hualde 1989: 183-185, Olson 1964, Polak 1986, Schlindwein 1986)

Shi (Polak-Bynon 1975: 210-212)

Wanga (Marlo field notes)

The Fuliiru data in (15), which show that Fuliiru allows two OPs with 1SG $N$ - and reflexive $y i-$, are noteworthy because the Fuliiru reflexive $y i$ - has a CV- shape, which is unlike many other languages that have a $\mathrm{V}$-shaped reflexive.

(15) Two OPs with 1SG $N$ - and reflexive $y i$-in Fuliiru (Van Otterloo 2011: 40-41)

a. w-à-bì-m[bééréz-â] 3SG-PST-8-1SG[give-FV]

'He's the one who gave them 8 to me.' 
b. ú-w-áàlí kìzí lù-yí[làsh-á]mwò

3SG-1-PST REP 11-REFL[throw-FV]18

'the one who threw himself in it 11 '

Sometimes either the $1 \mathrm{SG}$ OP or the reflexive but not the other licenses an additional OP. In Khayo, 1 SG $N$ - can co-occur with a second OP, but reflexive $i$ - cannot (Marlo 2009: 92). Bukusu is similar to Khayo in that two OPs are generally not allowed, as shown in (16a), but the situation with $1 \mathrm{SG} n$ - and reflexive $i$ - is reversed compared to closely related Khayo: $1 \mathrm{SG} n$ - cannot co-occur with a second OP (16b), but reflexive $i$ - can (16c).

(16) Two OPs with reflexive $i$ - in Bukusu (Diercks \& Sikuku 2011, Sikuku 2012)

a. *Wamalwa a-a-mu-ba[siim-isy-a]

Wamalwa 3SG-PST-3SG-3PL[cook-CAUS-FV]

'Wamalwa made him like them.'

b. Wekesa a-a-m[b-a] siitabu

Wekesa 3SG-PST-1SG[give-FV] 7-book

'Wekesa gave me the book.'

*Wekesa a-a-si-m[b-a]

Wekesa 3SG-PST-7-1SG[give-FV]

'Wekesa gave me it.'

c. Wekesa a-a-mu-i[siim-isy-a]

Wekesa 3SG-PST-3PL-REFL[like-CAUS-FV]

'Wekesa made him like himself.'

It is also possible for there to be two instances of the reflexive in Bukusu, where each instance of the reflexive represents a distinct thematic role, as in (17a). Another language that allows multiple instances of the reflexive, each indexing a distinct thematic role, is Ruwund, as shown in (17b).

(17) Two instances of the reflexive

a. Bukusu (Sikuku 2012)

Khalayi a-a-i-i[siim-isy-a]

Khalayi 3SG-PST-REFL-REFL[like-CAUS-FV]

'Khalayi made herself like herself.'

b. Ruwund (Nash 1992: 571)

kw-ii-yii[kis-ish]

INF-REFL-REFL[dirty-CAUS]

'to cause oneself to dirty oneself' 
In a number of other languages, either the $1 \mathrm{SG}$ OP or the reflexive licenses an additional OP, but we cannot at present be certain that the other prefix does not license a second OP. Polak (1986: 404) cites several other languages that allow two OPs just in case one is $1 \mathrm{SG} N$ - but does not specifically note that the reflexive does not license a second OP (presumably because the source materials were not explicit on the matter). Languages of this type are listed in (18). Yaka, a language usually characterized by one OP position and one object enclitic position, has an analogous pattern: two OPs are allowed just in case one is 1SG (Kidima 1987: 186).

(18) Languages that allow two OPs only if one is $1 \mathrm{SG} \mathrm{N}^{-}$

Libinza (Polak 1986: 404)

Luba-Kasai (Kuperus \& Mpunga wa Ilunga 1990: 34)

Lulua (Polak 1986: 404)

Ndengese (Polak 1986: 404)

Punu (Polak 1986: 404)

Suku (Nurse 2007, Polak 1986: 404)

Languages reported to allow two OPs just in case one is the reflexive include those in (19). Analogous patterns are found in Rundi (Meeussen 1959: 102) and Ruwund (Nash 1992: 571), in which three OPs are possible just in case one is the reflexive $i$-.

(19) Languages that allow two OPs only if one is the reflexive

Bakweri (Hawkinson 1986: 151-152)

Bukusu (Diercks \& Sikuku 2011, Sikuku 2012)

Havu (Polak 1986: 404)

Kikuyu (Barlow 1951: 266)

Lozi (Polak 1986: 404)

Tharaka (Muriungi 2008: 90, 121-122)

We sometimes find cases where the 1SG OP $N$ - licenses an additional OP but there are limited additional combinations of OPs that make it clear that the correct generalizations concerning the combinatorial possibilities of OPs involve non-phonological properties such as person and animacy. As shown by the examples in (20), Lungu allows two OPs just in case one is 1st person; in addition to $1 \mathrm{SG} n-$, $1 \mathrm{PL}$ tú- also licenses a second OP. The 1st person OP must represent the indirect object (goal/beneficiary), and there are ordering restrictions: 1PL tú- must be ordered first, and 1SG $n$ - must be ordered second. Other combinations of OPs are "very marginal or completely ungrammatical". 
(20) Two OPs in Lungu with 1SG N-or 1PL tú-(Bickmore 2007: 30)

a. yá-kú-múú-n[dém-él-à]

3PL-PRES-3SG-1SG[grab-APPL-FV]

'They are grabbing him for me.'

b. yá-kú- ${ }^{\downarrow}$ tú-mú ${ }^{\downarrow}[$ léém-él-à]

3PL-PRES-1PL-3SG[grab-APPL-FV]

'They are bringing him for us.'

A similar pattern is found in Nyambo: two OPs are generally allowed, but, as shown in (21), three are allowed just in case one is 1st person (Rugemalira 1997: 210, 2005: 89-90). A slight difference from the Lungu pattern is that in Nyambo both 1st person OPs must appear as the rightmost OPs.

(21) Three OPs in Nyambo with 1SG N- or 1PL tu- (Rugemalira 1991: 203, 1993a: 229, 2005: 90)

a. a-ka-ga-mu-m[pé-er-a]

3SG-PST-6-3SG-1SG[give-APPL-FV]

'He gave it ${ }_{6}$ to him for me.'

b. a-ka-ga-mú-n[siij-ir-a]

3SG-PST-6-3SG-1SG[smear-APPL-FV]

'She smeared $\mathrm{it}_{6}$ on him for me.'

c. a-ka-ga-mu-tu[nywé-ís-ez-a]

3SG-PST-6-3SG-1PL[give-CAUS-APPL-FV]

'He made her drink it ${ }_{6}$ for us.'

A third possible case in which any 1st person OP exceptionally licenses a second OP is Mongo. Virtually all attested examples of two OPs in Mongo involve 1SG $N$-, though Hulstaert (1965: 329330) notes that a few other OP combinations were observed in his corpus. All of the examples of other OP combinations that Hulstaert lists involve the 1PL OP.

In Bemba most combinations of OPs are not allowed, as indicated by the examples in (22a). However, two OPs are allowed if both are animate, as shown by (22b). 1SG $N$ - is even more permissive than other animate OPs: it can co-occur with an inanimate OP, as in (22c), or even with two OPs, provided that one is animate, as in $(22 \mathrm{~d}){ }^{7}$

7 Marten \& Kula (2012) do not argue against alternative statements of this generalization in terms of noun class features (i.e. cl. 1-2) or semantic features like [ \pm human]. 
(22) Restrictions on multiple OPs in Bemba (Marten \& Kula 2012: 245, Mwansa 2011: 19)

a. *n-àlíí-mù-yà[péél-à] *n-àlíí-yà-mù[péél-à]

1SG-PST-3SG-6[give-FV] 1SG-PST-3SG-6[give-FV]

'I gave him it $_{6}$. 'I gave him it 6 .'

b. mù-kà-bá-mú[éb-él-á]kó

2PL-FUT-3PL-3SG[tell-APPL-FV]17

'You will tell them for him.'

c. à-chí-m[péél-é]

3SG-7-1SG[give-APPL-FV]

'He should give it $t_{7}$ to me.'

d. mú-ká-cí-mù-n[twààl-íl-é] ${ }^{\downarrow}$ kó

2PL-FUT-7-3SG-1SG[return-APPL-FV]17

'You should return it to him/her for me.'

3.2 Towards an analysis. Before presenting my morpho-syntactic analysis, I briefly discuss two phonologically based accounts of the OP combination data which are intuitively appealing but which cannot stand up against the full range of data.

Polak (1986) observes that in CV-N-OP combinations with $1 \mathrm{SG} * \grave{n}$ - and in CV-V-OP combinations with reflexive $*_{i-}$, the two OPs are together only a single syllable in size, just as when there is only a single CV-OP. When two CV-OPs co-occur, the OPs together are two syllables in size. One could potentially implement this insight as a monosyllabic template on the OPs, which prevents CV-CV- combinations but allows CV-N- and CV-V-. However, a phonological analysis along these lines could not handle the facts of Fuliiru, Lungu, Nyambo, and Bemba, since OP combinations like -lu-yi- (15b), -tú-mú- (20b), -ga-mu-tu- (21c), and -bá-mú(22b) are clearly larger than a single syllable.

A second phonologically based analysis might propose that the $1 \mathrm{SG}$ OP $N$ - is able to license an additional OP because it phonologically fuses with the stem for reasons discussed in $\$ 2.2$. The empirical problem with this analysis is that it is a plausible account of the behavior of $1 \mathrm{SG} N$ - only; reflexive $i$ - also commonly licenses a second OP, yet there is no phonological motivation to parse $i$ - as part of the stem.

If there is a general analysis of the restrictions on combinations of OPs in the data described in this section, it is clear from the data in Lungu, Nyambo, and Bemba in (20) - (22) that morphosyntactic properties such as person and number features are responsible for the surface patterns. Following Buell (2005) on Zulu, Muriungi (2008) on Tharaka, and Sikuku (2012) on Bukusu, I analyze the data above as involving multiple structural positions for OPs. The basic idea, schematized in (23), is that there is an inner morpho-syntactic position for an additional OP, which is highly restricted in the features of the OPs that can appear in it. 
(23) Restrictions on multiple OPs

a. Languages that normally allow one $\mathrm{OP}: \mathrm{OP}_{2}$ is highly restricted

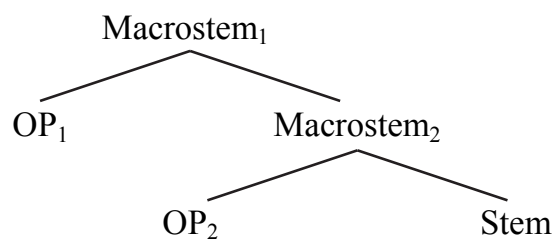

b. Languages that normally allow two OPs: $\mathrm{OP}_{3}$ is highly restricted

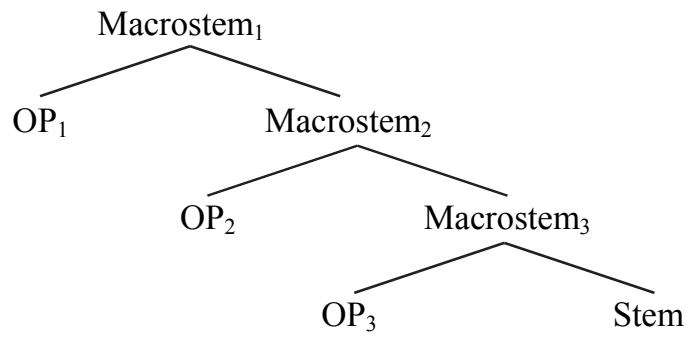

Some languages, like Khayo, restrict $\mathrm{OP}_{2}$ to $1 \mathrm{SG}$ only; some, like Bukusu, restrict it to reflexive only; some, like Nyaturu, restrict it to $1 \mathrm{SG}$ or reflexive; and some, like Lungu, restrict it to first person (singular or plural). (See Woolford 2000 for an alternative formal analysis of Nyaturu object-marking.) Nyambo has two less restricted $\mathrm{OP}$ positions, $\mathrm{OP}_{1}$ and $\mathrm{OP}_{2}$, but $\mathrm{OP}_{3}$ is restricted to first person.

Bemba's restrictions, which are in need of further study, are more complex and appear to require simultaneous reference to multiple OP slots. An additional analytical challenge is posed by languages like Tharaka, where there is evidence for a three-way structural division of OPs as in (8) above (Muriungi 2008: 121-122), but a maximum of two OPs, one of which must be 1SG or reflexive, is allowed at any one time. As discussed in Marlo (to appear), additional research is needed to develop explanatory, typologically informed accounts of the number of OPs allowed in individual Bantu languages.

\section{Allomorphy of the FV in the imperative}

In this section, we look more closely at the patterns of FV allomorphy found in the imperative, surveying the known variation across Bantu languages and proposing that the inner position of the $1 \mathrm{SG}$ OP (or rarely other OPs, such as the reflexive) is responsible for the differences in FV allomorphy patterns compared to other OPs, just as these structural differences can lead to differences in the number of OPs.

4.1 Micro-typological patterns. The pattern of FV allomorphy in the imperative described for Nyaturu is also found in Rundi, as shown in (24). 
(24) Imperative FV allomorphy in Rundi (Ndayiragije 2003: 183-185)
a. [vun-a] amagúfa
'Break the bone!'
b. tu[vun-e]
'Break us!'
c. i[vun-e]
'Break yourself!'
d. $\mathrm{m}[$ peb-a] $(/ \mathrm{N}[$ heb-a]/)
'Abandon me!'

The Rundi data in (24) are the basis of Ndayiragije's (2003: 183-185) phonological account of FV allomorphy in which it is proposed that the FV becomes $-e$ when the OP is an entire syllable on its own, but the FV surfaces as $-a$ elsewhere. The 1SG nasal OP does not condition the alternation to $e$ because as a prenasalized stop, it does not constitute a syllable. We see below, however, that this type of analysis does not extend to some other patterns of FV allomorphy.

Many other modern day Bantu languages, including those in (25), have the Nyaturu and Rundi pattern of FV allomorphy in the imperative. Meeussen (1962: 74, 1967: 112) reconstructs this common pattern to Proto-Bantu.

(25) Languages with the Nyaturu pattern of FV allomorphy in the imperative

Bajuni (Nurse n.d.: 23)

Fuliiru (Van Otterloo 2011: 40-41)

Ganda (Ashton et al. 1954: 29-31, 36, 65-66, 70, 93-96, 220-226)

Gweno (Marlo field notes)

Ha (Harjula 2004: 88-89)

Haya (Hyman \& Byarushengo 1984) ${ }^{8}$

Ila (Yukawa 1987c: 242)

Jita (Downing 1996: 35)

Kikuyu (Barlow 1951: 67, 70)

Marachi (Marlo 2007)

Mwimbi

Nyiha (Yukawa 1989e: 507-509)

Rundi (Meeussen 1959: 112, Ndayiragije 2003: 183-185)

Shi (Polak-Bynon 1975: 222-223)

some varieties of Swahili (Haddon 1955: 81)

Tiriki

Tsootso (Dalgish 1974: 85-88)

Tswana (Cole 1955: 241, Hyman 2001: 157, 162, Mmusi 1992)

Kamba (Angelina Kioko, p.c.) and Mwera (Harries 1950: 87, cited in Devos \& Van Olmen 2013) are similar to these languages, except that there is variation in the form of the imperative verb with the $1 \mathrm{SG}$ OP $N$-: the FV is optionally $-a$ or $-e$.

Some other languages have generalized the pattern of CV- OPs to the 1SG context such that all OPs trigger final $-e$. This pattern is found in languages with a CV-shaped 1sG OP (26a-d), in at

$81 \operatorname{sg} N$ - conditions an unexpected tonal pattern along with the FV - $a$ in the imperative in Haya (Hyman \& Byarushengo 1984: 66-67). 
least one language with an invariant syllabic nasal (26e), and in several languages with a nonsyllabic nasal (26f), as illustrated by the forms from Khayo in (27).

(26) Languages in which all OPs trigger the FV $-e$ in the imperative

a. $1 \mathrm{SG} n i-$ Mwenyi (Yukawa 1987b: 64)

Sukuma (Yukawa 1989b: 387-388)

Swahili

b. 1SG $n g u-$

Luvale (Yukawa 1987a: 64)

Makonde (Yukawa 1989f: 551-552)

c. $1 \mathrm{SG} n d i-$

Chewa (Ndayiragije 2003: 183)

d. 1 SG $n g i-$

Zulu (Engelbrecht 1957)

e. $1 \mathrm{SG} n^{-}$

Nilamba (Yukawa 1989c: 439-440)

f. $1 \mathrm{SG} N-$

Khayo (Marlo 2009)

Lungu (Bickmore 2007: 307)

Saamia (Botne et al. 2006: 51-52)

eastern Tswana (Cole 1955: 241)

Tura (Marlo 2008)

(27) Imperative FV allomorphy in Khayo (Marlo 2009: 111)

[liingaal-á] 'watch!'

mu[líingaal-é] 'watch him!'

n[íingaal-é] 'watch me!'

There are a number of other languages that show interesting variations on the Nyaturu/Rundi pattern of FV allomorphy in the imperative. Tharaka has the usual pattern of FV allomorphy, where bare stems (28a-b) and the 1SG $N$ - (28e) condition the FV - $a$, while other OPs (28c) and the reflexive (28d) trigger final $-e$. 
(28) Imperative FV allomorphy in Tharaka (Muriungi 2008: 118-123)
a. [ring-a]
'Hit!'
b. [ring-ith-i-a] John rû-thingo
'Coerce John to hit the wall!'
c. mî[ring-e]
'Hit it 9 !'
tû[tem-e]
'Cut us!'
mû[tem-e]
'Cut him!'
d. î[ring-e]
'Hit yourself!'
e. $n[$ tem-a]
'Cut me!'

However, Tharaka possesses an additional type of imperative form with an 'expletive' prefix $\hat{\imath}-$, which "appears to be semantically vacuous" and occurs only in imperatives (Muriungi 2008: 119). As shown in (29a), forms with this prefix end with the FV $-a$. As shown in (29b), expletive $\hat{l}$ - does not co-occur with an OP, a property shared with the anomalous initial $i$ - of some verbs in Sambaa, Mbugu, and Pare (Mous 2003: 112-113, Riedel 2009: 27; see Marlo 2014). Although a number of questions remain about expletive $\hat{\imath}$ - in Tharaka, ${ }^{9}$ the construction is important because it shows that Ndayiragije's (2003) phonologically driven account of FV allomorphy cannot account for the full range of Bantu patterns since Tharaka forms with expletive $\hat{\imath}$ - have a full syllable before the verb stem yet end in the FV - $a$ (Muriungi 2008: 118-123).

(29) Expletive $\hat{\imath}$-in Tharaka (Muriungi 2008: 119, 122)
a. $\hat{1}[$ tem-a]
'Cut!'
b. *în-n[tem-a] 'Hit me!
*î-n[tem-e] 'Hit me!'

Bukusu puts a rare twist on exceptional patterns of FV allomorphy in the imperative. Bare stems end in $-a(30 \mathrm{a})$, and most forms with an OP end in $-e(30 \mathrm{~b})$. The $1 \mathrm{SG}$ OP $n-(30 \mathrm{c})$ is like any other $\mathrm{CV}$-shaped OP in triggering final $-e$. Strikingly, the reflexive (30d) takes the FV $-a$. Recall that reflexive $i$ - is also unique in Bukusu in exceptionally licensing a second OP (see (16) above).

(30) Imperative FV allomorphy in Bukusu (Maurice Sifuna, p.c., Justine Sikuku, p.c., Sikuku 2012)
a. [bek-a] 'Shave!'
b. mu[bek-e] 'Shave him!'
c. m[bek-e] 'Shave me!'
d. i[bek-a] 'Shave yourself!' *i[bek-e] 'Shave yourself!'

Digo is another example of the familiar pattern of FV allomorphy in the imperative, where bare stems and stems with the 1SG OP take the FV $-a$, and forms with other OPs take the FV - $e$ (Kisseberth 1981: 95-97, 1984: 158). What makes the Digo data in (31) noteworthy is that the 1SG OP $n i$ - has a CV- shape and therefore constitutes a syllable of its own.

9 Only one example of expletive $\hat{\imath}-$ is provided in Muriungi (2008), and there is little additional information about the marker's meaning, function, and distribution. Expletive $\hat{\imath}^{-}$has the same vowel quality as reflexive $\hat{\imath}^{-}$, but since tone is not marked, it is not possible to verify the claim that the two prefixes are homophonous. We do not know how verbs with the expletive prefix compare tonally with bare imperative verbs and with imperative forms with OPs and the reflexive. 
(31) Imperative FV allomorphy in Digo (Kisseberth 1981: 95-97, 1984: 158)
a. [tfeketfer-a] 'Sift for!'
[tsukur-a] 'Carry!'
b. a[tfékétfer-e] 'Sift for them!' a[tsukûr-e] 'Carry them!'
c. ni[t feketfer-a] 'Sift for me!' ni[tsukur-a] 'Carry me!'

Other languages with the Digo pattern of FV allomorphy in the imperative are listed in (32). All of these languages have $1 \mathrm{SG} n i-$.

(32) Languages in which $1 \mathrm{SG} n i$ - triggers the FV $-a$ in the imperative

Chimwiini (Kisseberth \& Abasheikh 2004)

Giryama (Lax 1996: 267, 293-294, 301)

Mbaga Pare (Kagaya 1989: 142-145)

Mtang'ata Swahili (Whiteley 1956: 32, 33, cited in Devos \& Van Olmen 2013: 20)

A similar pattern is found in Machame Chaga (Yukawa 1989a: 324-326), where, as shown in (33), the $1 \mathrm{SG}$ OP $f$ - takes the FV $-a$ in the imperative, while other OPs including $3 \mathrm{SG} n$ - and 3PL $v a-$ take the FV $-e$. This example is phonologically notable because the 1SG OP has no association with nasal features.

(33) Imperative FV allomorphy in Machame Chaga (Yukawa 1989a: 324-326)
a. [kab-á] 'Beat!'
[ruúy-â] 'Look for!'
b. n $[$ kab-ê] 'Beat him!'
n[ruúy-ê] 'Look for him!' va[káb-ê] 'Beat them!' va[rúúy-ê]
'Look for them!'
c. $\int i[k a b-\hat{a}]$ 'Beat me!'
Ji[ruúy-â]
'Look for me!'

A further important variation on the most common pattern of exceptional allomorphy is found in Ndebele. As shown by the forms in (34), most OPs, including the reflexive, require the FV $-e$, but 1st person OPs optionally take final $-a$ or $-e$ (Sibanda 2004: 29, 112-114). As we see in (34d), not only does the 1SG OP ngi- trigger $-a$, but also the 1PL OP $s i$-. This generalization is analogous to the exceptional licensing of an additional OP by 1st person OPs in Lungu and Nyambo (see (20) (21) above).

(34) Imperative FV allomorphy in Ndebele (Sibanda 2004: 29, 112-114)
a. [that-a]
'Take!' [ph-an-a] yi[ph-a]
'Give!'
b. ba[thath-e] ba[ph-e]
'Take them!'
'Give them!'
c. zi[tshay-e] zi[ph-e]
'Hit yourself!
'Give yourself!'
d. ngi[tshay-a] $\sim$ ngi[tshay-e] 'Hit me!' si[ph-a $\sim$ si[ph-e] 'Give us!'


Another variant on the FV allomorphy patterns is found in Kwanyama (Halme 2004: 84-85). In imperative forms with an OP in (35b), the FV does not alternate but remains $-a .^{10}$ There is, however, a tonal alternation on the verb stem that does not appear related to the tone of bare imperatives in (35a). Imperative forms with the reflexive in (35c) also have the FV $-a$ and a special tonal pattern (Halme 2004: 86). Even two OPs in (35d) do not trigger a change of the FV from $-a$. Surprisingly, however, when the $1 \mathrm{SG}$ enclitic -nge is used, as in (35e), the FV changes to $e$ (with the same stem tone pattern as in other imperative + OP forms) - an alternation not triggered by the 1SG enclitic in other verb tenses (Halme 2004: 78, 86).

(35) Imperative FV allomorphy in Kwanyama (Halme 2004: 77-78, 84-86)
a. [dingílil-a] [endelél-á]
'Go round!'
b. mu[dip-aá]
'Hurry up!'
mu[nyol-él-á]
'Kill him/her!'
tu[lómbwel-á]
'Write him/her!'
c. li[nyeng-á]
'Tell us!'
d. ke-lí[kundík-á] mofíngo
e. [kwaf-é]ngé
'Move yourself!'
'Wind it ${ }_{12}$ around your neck!'
'Help me!'

4.2 A morpho-syntactic analysis. I largely adopt Muriungi's (2008) morpho-syntactic analysis of the imperative allomorphy patterns in Tharaka and suggest ways of adapting this approach to account for a broader range of data across Bantu. Muriungi proposes that $1 \mathrm{SG} N$ - and expletive $\hat{l}^{-}$ in Tharaka trigger different FVs from other OPs because these morphemes occupy a lower structural position than other OPs. In this approach, the FV - $a$ is treated as the 'default', and final $e$ "is inserted in some specific environments ... [such as] when there are prefixes higher than (and including) reflexive in the clausal hierarchy in imperatives (Muriungi 2008: 123)." As evidence for his analysis of 1SG below the reflexive and other OPs, illustrated by (8) above, Muriungi observes that $1 \mathrm{SG} N$ - follows reflexive $\hat{\imath}$ - when the two co-occur in Tharaka, as in (7b) above. ${ }^{11}$

Differences in the phonological quality of $1 \mathrm{SG}$ in languages like Digo and Machame Chaga have no impact on Muriungi's (2008) analysis, which is concerned only with the structural position of the 1SG OP compared to other OPs, so as long as 1SG is structurally lower than other OPs, as in (36). Muriungi's analysis should straightforwardly extend to these languages.

10 Other languages that have an invariant FV - $a$ in the imperative, even with OPs, are Ngombe (Meeussen 1962, Yukawa 1992: 296) and Yaka (Kidima 1991: 119-121). Invariant Zulu imperative forms with final $a$ are considered 'emphatic' (Engelbrecht 1957: 105-106).

11

See Buell (2005: 134) for an alternative syntactic analysis of the different properties of the 1sg OP in languages like Rundi, in which a crucial assumption is that the $1 \mathrm{sg}$ OP is structurally lower than other OPs. 
(36) 1SG below other OPs (Digo, Machame Chaga)

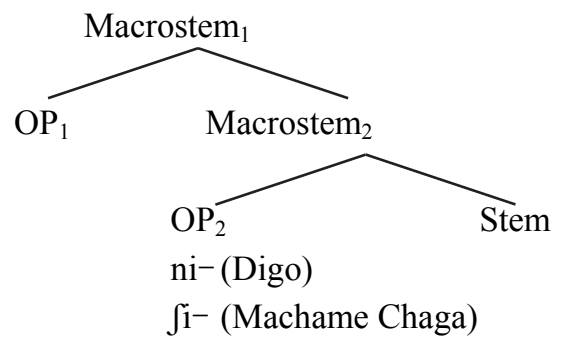

Muriungi's analysis extends easily to Bukusu. The only difference compared to Tharaka is that in Bukusu the reflexive is the structurally lowest OP (Sifuna 2012), as in (37). Recall from (6a) that the reflexive follows the $1 \mathrm{SG}$ OP in Bukusu. Two consequences of this lower position of the reflexive are that (i) the reflexive licenses a second OP and (ii) it triggers final $-a$ in the imperative. Thus, the rule that inserts final $-e$ in Bukusu applies when there are prefixes higher in the tree than the reflexive.

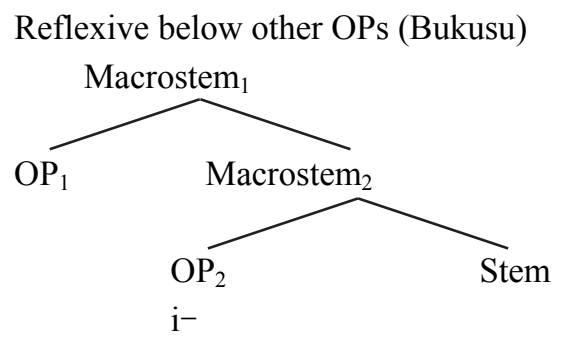

Under a Muriungi-style analysis, I propose that the 1st person (singular and plural) OPs of Ndebele are structurally lower than other OPs. The rule inserting final $-e$ is variable in the level of the tree that it is sensitive to - it varies in including or excluding the 1st person OPs - as in Kamba and Mwera, where only $1 \mathrm{SG}$ is structurally lower than other OPs.

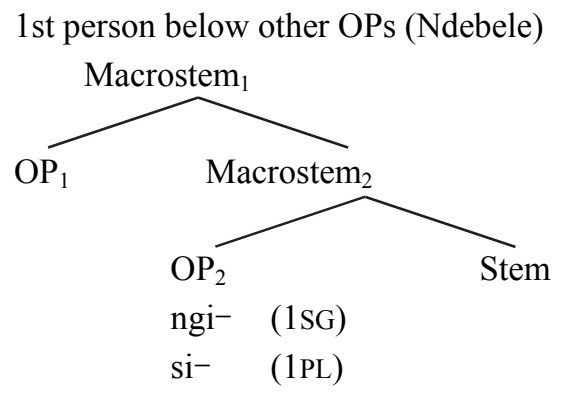

Muriungi's approach could be adapted to Kwanyama by proposing that the rule inserting final $-e$ is sensitive to the presence of enclitics following the verb, as opposed to elements preceding (structurally higher than) the verb in most other languages.

For languages where the 1SG is like other OPs in triggering the FV - $e$ in the imperative, such as Khayo (see (27) above), it may still be the case that the 1SG is structurally lower than other OPs, 
which may have other morpho-syntactic consequences such as exceptionally licensing an additional OP, as 1SG does in Khayo (Marlo 2009: 92). However, in such languages, the rule that inserts final $-e$ is not sensitive to the structural difference between $1 \mathrm{SG}$ and other OPs-any structure larger than the verb stem yields final $-e$.

One issue that must be dealt with in extending a Muriungi-style analysis of FV allomorphy patterns to other Bantu languages is how to account for languages like Rundi, which have the same general patterns of allomorphy as Tharaka (see (24) above) but which have the reverse surface order of $1 \mathrm{SG}$ and reflexive. As shown in (6b) above, reflexive $i$ - follows $1 \mathrm{SG} N$ - in Rundi and by Baker's (1985) Mirror Principle should therefore be structurally lower than 1SG. A direct translation of Muriungi's (2008) analysis (as well as Buell's 2005 analysis) to Rundi predicts that the FV would be - $a$ with the reflexive and with bare verb forms, but $-e$ with $1 \mathrm{SG} N$ - and other OPs. One possibility would be to propose that in terms of the underlying syntactic structure of the $1 \mathrm{SG}$ OP and the reflexive, Rundi has the same structure as Muriungi (2008) proposes for Tharaka, with the 1SG OP lower than reflexive. It is this structure that regulates the choice of FV. However, after the choice of FV has been determined, a later reordering of these prefixes subsequently takes place, such that the reflexive is pronounced closer to the stem.

4.3 FV $-e$ and the imperative-subjunctive connection. To conclude this section, I discuss in greater detail the FV $-e$ and the contexts in which it is found, including the subjunctive.

In addition to OPs, other prefixes such as andative $k a$ - 'go and' trigger the FV $-e$ in the imperative (Buell 2005: 134-135, Muriungi 2008: 120, Polak 1986). Plural and negative forms of the imperative, which, unlike affirmative imperative singular forms with an OP, have a SP, sometimes also take a FV other than $-a$, such as $-e$ or $-i$, as in Nyaturu (Olson 1964).

It is unclear if the FV in these contexts has any formal connection to imperative forms with an $\mathrm{OP}$, or whether any resemblances in the phonetic content of the FV is synchronically accidental. Across Bantu, the realization of the FV and other inflectional morphemes in the verb-such as subject agreement, tense-aspect markers, and stem tonal melody-is complex (see, e.g., Buell 2005: 71-135 on Zulu). As Marlo (2013) discusses, the many factors involved in determining how these morphemes are pronounced include several morpho-syntactic parameters, such tense-aspect distinctions, polarity, the clause type, and conjoint/disjoint distinctions, which sometimes signal whether the verb is phrase-final and in which focus sometimes plays a role. The analysis proposed in the preceding section adds a further morpho-syntactic parameter for determining the FV of imperative verb forms: whether there is morpho-syntactic structure above or below a given point in the clausal hierarchy.

As Buell (2005) points out, the FV $-e$ is characteristic of the subjunctive, and imperative + OP forms with final $-e$ are often identified as formal subjunctives in Bantu languages. Several languages are listed in (39) in which imperative forms with an OP are identical to subjunctive forms with an OP. To these languages, we can add Zulu, in which, according to Engelbrecht (1957: 106), imperative forms with $-e$ are tonally identical to subjunctives and may be treated as "a subjunctive without a subjectival concord". Similarly, Kinga has tonal connections among imperative forms with an OP, the subjunctive, plural imperatives, and tenses that are "nearly all descendants of the Bantu subjunctive plus object prefix construction" (Odden 1989: 229). 


Imperative + OP $=$ subjunctive + OP (Meeussen 1962: 74)
Bemba Bembe Gusii Holoholo Konzo
Lega $\quad$ Sotho

A further reason to potentially connect imperatives and subjunctives concerns their behavior under negation. ${ }^{12}$ In a number of languages, both inside and outside of Bantu, subjunctive and nonsubjunctive verbs employ distinct negative markers, and imperatives commonly take the subjunctive pattern of negation (see e.g. Zanuttini 1997). According to Nurse (2008: 44), the most common way to form a negative command in Bantu languages is with the subjunctive. This can be seen in the Swahili forms in (40), where imperative (sg.) forms take the FV - $a$ and have no prefix morphology, while negative imperatives have the 2SG SP $u$-, negative $s i$-, and the FV $-e$, which is identified as the subjunctive suffix (Ngonyani 2001: 22). ${ }^{13}$ Main clause indicative forms employ a different negation strategy, with the negative marker $h a-$, which precedes the SP and tense-aspect prefixes.

(40) Affirmative and negative verb forms in Swahili (Ngonyani 2001)

\begin{tabular}{|c|c|c|}
\hline Imperative & $\frac{\text { Affirmative }}{\text { [som-a] }}$ & $\begin{array}{l}\text { Negative } \\
\text { u-si[som-e] }\end{array}$ \\
\hline & 'Read (sg.)!' & 'Do not read (sg.)!' \\
\hline Future & wa-ta[ondok-a] & ha-wa-ta[ondok-a] \\
\hline \multirow[t]{2}{*}{ Present } & $\begin{array}{l}\text { 'They will leave.' } \\
\text { wa-na[ondok-a] }\end{array}$ & $\begin{array}{l}\text { 'They will not leave.' } \\
\text { ha-wa[ondok-i] }\end{array}$ \\
\hline & 'They are leaving.' & 'They are not leaving. \\
\hline \multirow[t]{2}{*}{ Past } & wa-li[ondok-a] & ha-wa-ku[ondok-a] \\
\hline & 'They left.' & 'They did not leave.' \\
\hline \multirow[t]{2}{*}{ Perfect } & wa-li[ondok-a] & ha-wa-ja[ondok-a] \\
\hline & 'They left.' & 'They did not leave.' \\
\hline
\end{tabular}

Buell's (2005: 131-132) formal syntactic analysis of FV allomorphy in Zulu builds on this connection between the imperative and the subjunctive. The key idea is that imperative forms with an $\mathrm{OP}$ are impossible due to a syntactic filter that prevents the imperative verb plus OP structure from raising into the complementizer domain. Since the OP also cannot be left behind as the verb raises, a 'surrogate' form is adopted, a subjectless subjunctive, which is not restricted in the same way that morphological imperative plus OP forms are.

While this analysis of the imperative-subjunctive connection might be an acceptable analysis of some languages, it fails as a general account within Bantu, since there are languages such as the Marachi and Nyala-West dialects of Luyia (Marlo 2007) and Shangaci (Devos \& Van Olmen 2013) where the imperative plus OP combination is tonally imperative, not subjunctive, even though the FV changes to $-e$ in imperative forms with an OP. Similarly, even though the

12 Thanks to Brent Henderson for bringing this connection to my attention.

13 Lesson 55 of the University of Kansas Swahili lessons (http://www2.ku.edu/ kiswahili/) gives examples of the affirmative subjunctive such as afadhali $u$ [lal-e] sasa 'it is better if you sleep now', $u$ [sameh-e] 'you should forgive', fungua kitabu $u$ [som-e] 'open the book and read (it)', tu-wa[fundish-e] kimaasai 'let's teach them Maasai', and lazima $u[$ andik-e] barua 'you must write a letter'. 
Kwanyama verb has a different FV with the 1SG enclitic compared to other object markers in the imperative, the verb still undergoes the same tonal alternations with the 1 SG enclitic as with other object markers (see (35) above).

As Devos \& Van Olmen (2013) observe for a large number of languages they refer to as 'hybrids', imperative forms that take the FV $-e$ with an OP do not fully resemble subjunctives, as subjunctives have a SP, while imperative forms with an OP generally lack a SP. While Buell (2005) treats such forms in Zulu as a subtype of subjunctive, there is reason to think that in at least some Bantu languages, the morphology of imperative forms with an OP (the presence vs. absence of a SP, the selection of the FV, and the choice of tonal suffixes) does not involve a full-fledged shift to the subjunctive and may not refer to the concept 'subjunctive'.

We must also critically assess any claim that negative imperative forms are identical to subjunctives or some other verb tense, such as a narrative or future (see Devos \& Van Olmen 2013) on the sole basis of the identity of the FV and/or a tense prefix. For most languages, there is insufficient tonal data to be able to evaluate whether the negative imperative form is truly identical to the other subjunctive form or tense in question. As with imperative + OP combinations, Devos \& Van Olmen (2013) document hybrid negative imperative forms that share properties with, but are not fully identical to, negative subjunctives. Moreover, they identify other languages in which negative imperatives and subjunctives have unexpected morpho-syntactic properties: (i) some do not have final $-e$ in these contexts, (ii) some have a pre-initial instead of a post-initial negative prefix, and (iii) some are characterized by both (i) and (ii).

\section{Reduplication}

This section discusses further the exceptional behavior of OPs in reduplication. Additional data from Hehe are introduced in $\$ 5.1$ which show that the overcopying of OPs in reduplication has a morpho-phonological basis, and $\$ 5.2$ identifies analogous non-reduplicative patterns from other languages which have a parallel analysis. $§ 5.3$ describes a second phonological motivation for overcopying OPs in reduplication — minimality effects—-found in a number of languages, and §5.4 provides an overview of the cross-Bantu variation in the specific OPs that overcopy in reduplication.

5.1 Micro-typological patterns. Verb reduplication is a common and relatively well studied phenomenon in Bantu languages, which involves the doubling of the stem (see Downing 1994, 1999b, c, 2000, 2004, 2006, 2009, Hyman 2009, Hyman et al. 2008, Matondo 2003, Odden 1996, Odden \& Odden 1985, Poletto 1998, among others). As the stem is generally the domain of reduplication, OPs are generally not reduplicated. The overcopying of the 1SG OP, as we saw in Hehe in (3c), however, is a fairly common phenomenon.

Given the phenomena discussed in $\S 3-\S 4$, we might ask whether the 1SG prefix overcopies for morpho-syntactic reasons, perhaps because it is in a lower morpho-syntactic position than other OPs. It is clear that the answer to this question is "no". The overcopying of the 1sG prefix in Hehe reduplication has a primarily phonological explanation, as other OPs and other prefixes that are not OPs also overcopy under the right phonological conditions (Downing 1998b, Odden \& Odden 1985, and references therein). As shown in (41a), the 1SG SP $n$-also overcopies when it immediately precedes the stem, and any CV-shaped prefix, including OPs and other types of inflectional prefixes, is overcopied in the reduplication of $\mathrm{V}$-initial verbs, as shown in (41b). 
(41) Overcopying of other prefixes in Hehe reduplication (Odden \& Odden 1985)

a. [yuul-ite][yúul-ite]

[1SG.RED][1 SG.uproot-Fv]

'I have uprooted!' (/-kuul-/ 'uproot')

b. kw[íita][kw-iít-a] kú-lw[iita][lw-iít-a]

INF[RED][INF-pour-FV] INF-11[RED][11-pour-FV]

'to pour a bit' 'to pour it 11 a bit'

Downing (1998b) proposes that the overcopying of nasal prefixes from outside the stem in reduplication is the result of a constraint banning segmental features from being shared across the prefix-reduplicant boundary (Itô \& Mester 1994, 1999; see also Kawahara 2008). Since the nasal prefix undergoes place assimilation with the following consonant and thus shares place features with the following consonant, the assimilated nasal is brought into the reduplicant, and the nasal is backcopied to the base due to base-reduplicant identity. Principles of syllabification are responsible for the overcopying of $\mathrm{CV}$ - prefixes with $\mathrm{V}$-initial stems, due to a requirement that the 'Pstem' - a proposed morpho-prosodic constituent built on the morpho-syntactic stem-begin with an onset consonant.

5.2 Other stem-based phonological generalizations. There are also some non-reduplicative phenomena in Bantu languages in which some OPs behave as though they are stem-initial with respect to a morpho-phonological generalization.

A first example is found in Rundi future tense forms. As shown in (42), the Rundi infinitive prefix is $k u$-, which appears as $k w$ - before a $\mathrm{V}$-initial stem.

(42) Infinitives in Rundi (Aronoff 1988, Downing 1998b)
a. $\mathrm{ku}$ [moot-a] 'to smell' $\mathrm{ku}$ [rgy-a] 'to bite' $\mathrm{ku}$ [ramuts-a] 'to visit'
b. kw[oodz-a] 'to wash' kw[uumvir-a] 'to listen'

As shown in (43a), C-initial stems follow the future marker $d z o$ - with no alternation, but when no other prefix intervenes, a V-initial stem surfaces in its infinitival form with $k w$-, as in (43b). In combination with an OP, which intervenes between the future marker and the stem in (43c), the OP syllabifies with a V-initial stem, blocking augmentation of the verb stem with $k w$-.

(43) The Rundi future (Aronoff 1988, Downing 1998b)
a. a-dzo[ramuts-a]
'He will visit.'
b. a-dzo-kw[oodz-a]
'He will wash.'
c. a-dzo-y[oodz-a]
'He will wash it ${ }_{9}$ '

Downing (1998b) proposes that the future marker $d z o$ - subcategorizes for a C-initial Pstem. In combination with $d z o-$, a $\mathrm{V}$-initial stem is augmented with $k w$ - so that the Pstem begins with a $\mathrm{C}$, 
but when an OP is present, the OP, outside the morpho-syntactic stem, is incorporated into the Pstem, and the $\mathrm{C}$ of the $\mathrm{OP}$ satisfies the subcategorization requirement, so augmentation is unnecessary. Since any OP will satisfy the requirement when combined with a V-initial prefix, only a phonologically based analysis is possible.

An analogous phenomenon is found in Basaa. Basaa has a stem-based pattern of voicing alternations in stops in which the $\mathrm{C}$ of $\mathrm{CV}$ - prefixes acts like it is stem-initial (Hyman 2003b, 2007: 202-203, 2008: 334). Basaa has a single series of stops /P, T, K/, which are realized as voiceless stop variants in stem-initial position but as voiced (and often continuant) variants in other positions. When a CV-prefix co-occurs with a V-initial stem, the prefix consonant is realized as the voiceless stop variant-in other words, as though it is stem-initial. As shown in (44), the cl. 13 prefix /Tì-/ is realized as ri- in stem-external position but as the stem-initial voiceless variant $t$ - - in combination with the $\mathrm{V}$-initial root.

(44) Stem-initial phonotactic alternations in Basaa

\begin{tabular}{|c|c|c|}
\hline /Tì-nùní/ & rì-nùní & 'birds 13 ' \\
\hline /TíTKí/ & tírgí & 'small' \\
\hline /TíTKí/ & rì-kórá & ' $\operatorname{pipes}_{13}$ ' \\
\hline /Kذ̀Knà/ & kòynà & 'crush each other' \\
\hline /Tì-Tám/ & ri-tám & 'kidneys 13 ' \\
\hline /Pì-Pà/ & 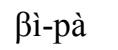 & 'machete 8 ' \\
\hline . /Tì-áy/ & t f-ăy & 'leaves 13 ' \\
\hline /Tì-oy/ & $\mathrm{t} \int-o \eta$ & 'hairs 13 ' \\
\hline
\end{tabular}

Kukuya is described as having a similar pattern in which prefixes fuse with a V-initial stem but otherwise form a separate domain preceding the stem (Hyman 1987: 325-326, 2008: 334, Paulian 1975). These alternations are transparently phonological in nature and are amenable to a Pstembased analysis, in which the Pstem expands to include the prefix as a result of syllabification principles.

5.3 Minimality-driven overcopying. In addition to the $\mathrm{CV}+\mathrm{V}$ and nasal prefix contexts, prefixes can also be overcopied in Bantu reduplication when a minimality requirement is imposed on the base or reduplicant. In several Bantu languages, including those in (45), OPs can be recruited into an otherwise subminimal reduplicative stem to meet the minimality requirement.

(45) Languages in which an OP can a minimality condition in reduplication Bukusu (Mutonyi 2000: 111)

Lungu (Bickmore 2007: 317)

Ndebele (Hyman et al. 2008, Sibanda 2004: 304-307)

Nkore (Poletto 1998: 177)

Sukuma (Matondo 2003)

Tharaka (Muriungi 2008: 110) 
As shown in (46), one strategy to augment a monosyllabic stem to meet the disyllabic minimality condition in Ndebele is to incorporate an OP (zi-) into the stem and copy it.

(46) OP satisfies a minimality condition in reduplication in Ndebele

\begin{tabular}{|c|c|c|}
\hline \multirow[t]{3}{*}{ Non-reduplicated } & Reduplicated & \\
\hline & uku-zi[thuma][thum-a] & 'to send them' \\
\hline & *uku-zi[thu][zi-thum-a] & 'to send them' \\
\hline b. uku-zi[dl-a] & uku-zi[dla][zi-dl-a] & 'to eat them' \\
\hline
\end{tabular}

The only case I am aware of where the reflexive prefix is overcopied in reduplication is the Tharaka example in (47), where reflexive co-occurs with a monosyllabic stem, and overcopying satisfies a bisyllabic minimality requirement on reduplication (Muriungi 2008: 110).

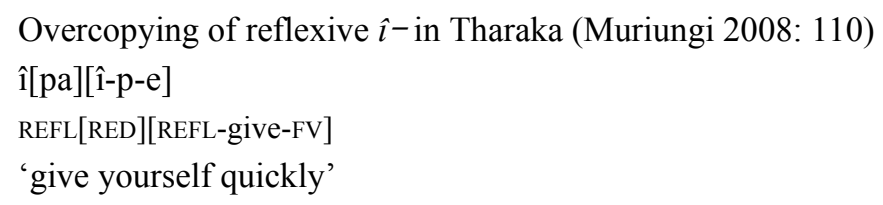

Overcopying of the reflexive might also be found in examples where the reflexive is lexicalized with the verb root, though I have not identified any such examples. The fact that the reflexive generally does not overcopy in reduplication is not surprising since $*_{i}$ - is syllabified in a syllable separate from the stem-initial consonant.

5.4 Cross-Bantu variation in overcopying. There are differences among Bantu languages in the contexts in which overcopying is found. Although phonological factors are primary in triggering the overcopying of segments of OPs, morpho-syntactic structure also contributes to micro-level variation in reduplicative patterns by limiting the types of prefixes that can overcopy.

The Hehe pattern of overcopying in both $\mathrm{CV}+\mathrm{V}$ and nasal prefix contexts in verbal reduplication is known to occur in one other language: Kamba (Angelina Kioko, p.c.). Kerewe (Odden 1996) and Nande (Mutaka \& Hyman 1990) also have reduplication in these two contexts, but in nominal, not verbal, reduplication. Sukuma has optional overcopying of cl. $9 \mathrm{~N}$ - in nominal and adjectival reduplication (Matondo 2003), and Nzadi has obligatory reduplication of 1SG $N$ - in verbal reduplication marking the future tense, which is unusual among OPs in the language in its prosodic coherence with the verb stem (Hyman 2011: 33-35). Other languages where CV-prefixes overcopy in combination with a V-initial verb stem are Ndebele (Sibanda 2004: 310) and Sukuma, which has optional overcopying in verbal, nominal, and adjectival reduplication (Matondo 2003).

Not all Bantu languages overcopy in both $\mathrm{CV}+\mathrm{V}$ and nasal prefix contexts. For example, in the Saamia dialect of Luyia, CV-prefixes are not overcopied with C-initial stems or V-initial stems, as shown in (48a-b), but the nasal 1 SG subject and object prefixes are overcopied, as shown in (48c-d). 
(48) Patterns of (non-)overcopying in Saamia (Botne et al. 2006, Marlo 2002, 2004)

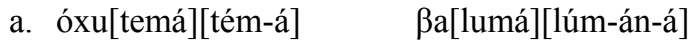

INF[RED][chop-FV] 3PL[RED][bite-REC-FV]

'to cut into pieces' 'They are biting each other continually.'

y-aa[batfá][bátf-íré] a-ká[lakásyá][lákásy-á]

3SG-PST[RED][cheat-FV] 3SG-6[RED][drop-FV]

'He cheated repeatedly.' 'He is dropping them 6 .'

b. óxw[iimbá][ímb-á]

y[ootá][ót-á]

INF[RED][sing-FV]

3SG [RED][warm-FV]

'to sing repeatedly'

'He is warming himself repeatedly.'

y[eexálá][íxál-á] (/-ixal-/)

Ø-mw[íimbá][ímb-ír-ááng-á]

$3 \mathrm{SG}[\mathrm{RED}][\mathrm{sit}-\mathrm{FV}]$

1SG-3PL[RED][sing-APPL-HAB-FV]

'He is sitting down repeatedly.' 'I am always singing for him.'

c. á-n[imbírá][n-ímb-ír-á] (/-imb-/)

3SG-1SG[RED][1SG-sing-APPL-FV]

'He is singing for me continuously.'

y-aá-n[aangíré][n-ááng-íré] (/-laang-/)

3SG-PST-1SG[RED][1SG-call-FV]

'He called me repeatedly.'

d. n[umá][n-úm-á] (/-lum-/) n[omá][nóm-á] (/-lom-/)

$1 \mathrm{SG}[\mathrm{RED}][1 \mathrm{SG}-\mathrm{bite}-\mathrm{FV}] \quad$ 1SG[RED][1SG-talk-FV]

'I am biting all over.' 'I am talking.'

Lungu has the reverse pattern compared to Saamia. As shown in (49a), a CV- object prefix optionally overcopies in combination with a V-initial stem. However, as shown in (49b), the $1 \mathrm{SG}$ OP $N$ - cannot overcopy.

(49) Patterns of (non-)overcopying in Lungu (Bickmore 2007: 318)

a. yá-kú-m[úúmá][m-úúm-à]

yá-kú-m[úúmá][úúm-à]

3PL-PRES-3SG[RED][3SG/Ø-beat-FV]

'They are beating him repeatedly.' 
b. yá-kúú-ndz[ímbá][ímb-à]

*yá-kúú-ndz[ímbá][ndz-ímb-à]

3PL-PRES-1SG[RED][Ø/1sG-dig.up-FV]

'They are digging me up repeatedly.'

In addition to having differences in the phonological contexts where overcopying applies, Bantu languages also differ in the types of prefixes that overcopy. Some languages like Hehe allow any type of prefix to be overcopied: an OP, infinitival prefix, SP, etc. Similarly, both the 1SG SP Nand the 1SG OP $N$ - are overcopied when they immediately precede the stem in Saamia reduplication. Other languages restrict the prefixes that may overcopy to OPs only. In several languages, including those in (50), the only type of prefix that overcopies with monosyllabic stems is an OP. Similarly, only OPs overcopy with V-initial stems in Lungu.

(50) Languages in which only OPs may satisfy a minimality condition in reduplication

Lungu (Bickmore 2007: 317-318)

Ndebele (Sibanda 2004)

Nkore (Poletto 1998: 202-211)

Tharaka (Muriungi 2008: 110)

The source of this variation is clearly structural. Muriungi (2008) takes the fact that only the OPs and reflexive can overcopy as evidence that these morphemes occupy a different structural position from other prefixes - a view that is consistent with the distinction between the macrostem, which includes the OPs, and the pre-macrostem inflectional prefixes (Myers 1990), which excludes the OPs. Thus, although the motivations for overcopying in reduplication are phonological, the effects are constrained by morpho-syntactic considerations.

\section{Conclusion}

This article has amassed a considerable database of exceptional properties of the 1SG and reflexive $\mathrm{OP}$, including the licensing of one more OP than is normally allowed, triggering the pattern of FV allomorphy found when there is no OP, and overcopying in reduplication. Within each of these phenomena, we have seen considerable variation across Bantu in the precise details of the exceptional patterns. I have argued that the exceptional patterns of OP combinations and allomorphy of the FV in the imperative are the result of the lower structural position of these morphemes, closer to the stem, as proposed by Buell (2005), Muriungi (2008), and Sikuku (2012) in their analyses of individual Bantu languages. Overcopying in reduplication, however, has a phonological motivation, as proposed in several papers by Laura Downing. Although more work is required to provide fully fleshed out formal analyses of all relevant object marking data in all of the languages mentioned here, this article brings us some distance in clarifying how the components of grammar interact to produce analytically challenging exceptional behavior of the $1 \mathrm{SG}$ and reflexive OPs in Bantu languages. 


\section{Acknowledgements}

This paper was previously circulated with the titles "Flexible stems in Bantu" and "Prefix-stem fusion in Bantu"; this version supersedes all previous drafts. I would like to thank Tucker Childs and the anonymous reviewers for their detailed and helpful feedback as well as several others who assisted me throughout the long gestation of this article: Alfred Anangwe, Lee Bickmore, Robert Botne, Vicki Carstens, Andries Coetzee, Gerry Dalgish, Michael Diercks, Laura Downing, Kristopher Ebarb, Jeff Heath, Brent Henderson, Larry Hyman, Billy Jivetti, Patrick Jones, Yuni Kim, Angelina Kioko, Yahya Kishashu, Rose Letsholo, Aaron Mbogho, Laura McPherson, Penina Memba, Bibiana Mwali, Chacha Mwita, Meshack Nderema, Derek Nurse, Hannington Ochwada, David Odden, Kenneth Okumu, Peter Otiato Ojiambo, Mary Paster, Ken Safir, Don Salting, Maurice Sifuna, Jastino Sikuku, Sally Thomason, Jonathan Wabala, John Ojiolloh Wambakha, Aggrey Wasike, and Doug-Jolene Wicks. I also acknowledge feedback from audiences at Maryland, Michigan, Missouri, Ohio State, Pomona College, UCLA, USC, ACAL 35, NAPhC 3, and the 82nd Annual Meeting of the LSA. This work has benefited from financial support from an NSF Graduate Research Fellowship, NSF Doctoral Research Improvement Grant 0545246, an NEH Summer Stipend, grants from the Department of Linguistics, Rackham School of Graduate Studies, and Center for Afroamerican and African Studies at the University of Michigan, and research leave provided by the Department of English and the Research Council at the University of Missouri. Any views, findings, conclusions, or recommendations expressed in this publication do not necessarily reflect those of anyone but the author.

\section{Abbreviations Used}

$\begin{array}{llll}1 \mathrm{SG} & \text { first-person singular } & \text { 1PL } & \text { first-person plural } \\ 2 \mathrm{SG} & \text { second-person singular } & \text { 2PL } & \text { second-person plural } \\ 3 \mathrm{SG} & \text { third-person singular } & \text { 3PL } & \text { third-person plural } \\ \text { APPL } & \text { Applicative } & \text { PRES } & \text { present } \\ \text { CAUS } & \text { Causative } & \text { PST } & \text { past } \\ \text { DISJ } & \text { Disjoint } & \text { REC } & \text { reciprocal } \\ \text { FOC } & \text { Focus } & \text { RED } & \text { reduplicant } \\ \text { FUT } & \text { Future } & \text { REFL } & \text { reflexive } \\ \text { FV } & \text { final vowel } & \text { REP } & \text { repetitive } \\ \text { HAB } & \text { Habitual } & \text { PL } & \text { plural } \\ \text { INF } & \text { Infinitive } & \text { TNS } & \text { tense } \\ \text { PERF } & \text { Perfective } & & \end{array}$

Noun class numbers are indicted by the numeral in interlinear glosses and as a subscript in translations ("it 7 " refers to noun from cl. 7). The verb stem is indicated with brackets, and the macrostem is indicated with braces. 


\section{References}

Adams, Nikki. 2010. The Zulu ditransitive verb phrase. Chicago, IL: University of Chicago Ph.D. dissertation.

Alsina, Alex. 1994. Bantu multiple objects: analyses and fallacies. Linguistic Analysis 24. 153174.

Archangeli, Diana \& Douglas Pulleyblank. 2002. Kinande vowel harmony: domains, grounded conditions, and one-side alignment. Phonology 19. 139-188.

Aronoff, Mark. 1988. Head operations and strata in reduplication: A linear treatment. Yearbook of Morphology 1. 1-15.

Ashton, Ethel O., Enoch M. K. Mulira, E. G. M. Ndawula \& Archibald Norman Tucker. 1954. A Luganda Grammar. London, New York \& Toronto: Longmans, Green \& Co.

Baker, Mark. 1985. The Mirror Principle and morpho-syntactic explanation. Linguistic Inquiry 16: 373-415.

Baker, Mark. 2008. The syntax of agreement and concord. Cambridge: Cambridge University Press.

Barlow, A. Ruffell. 1960. Studies in Kikuyu grammar and idiom. Edinburgh: Blackwood.

Barrett-Keach, Camillia. 1980. The syntax and interpretation of the relative clause construction in Swahili. New York: Garland Press.

Barrett-Keach, Camillia. 1986. Word-internal evidence from Swahili for Aux / INFL. Linguistic Inquiry 17. 559-564.

Bax, Anne \& Michael Diercks. 2012. Information structure constraints on object marking in Manyika. Southern African Linguistics and Applied Language Studies 30. 185-202.

Bearth, Thomas. 2003. Syntax. In Derek Nurse \& Gérard Philippson (eds.), The Bantu Languages, 127-142. London: Routledge.

Beaudoin-Lietz, Christa, Derek Nurse \& Sarah Rose. 2004. Pronominal object marking in Bantu. In Akinbiyi Akinlabi \& Oluseye Adesola (eds.), Proceedings of the 4th World Congress of African Linguistics, New Brunswick 2003, 175-188. Köln: Rüdiger Köppe.

Bentley, Mayrene. 1994. The syntactic effects of animacy in Bantu languages. Bloomington, IN: Indiana University Ph.D. dissertation.

Bickmore, Lee. 2007. Cilungu phonology. Stanford, CA: CSLI Publications.

Botne, Robert, Hannington Ochwada \& Michael Marlo. 2006. A grammatical sketch of the Lusaamia verb. Köln: Rüdiger Köppe.

Boyd, Ginger. 2008. Vowel harmony in ten A40-A60 Mbam languages. Paper presented at Annual Conference on African Linguistics 39. University of Georgia, April 17-20.

Bresnan, Joan \& Sam Mchombo. 1987. Topic, pronoun, and agreement in Chicheŵa. Language 63. 741-782.

Buell, Leston. 2005. Issues in Zulu verbal morpho-syntax. Los Angeles, CA: University of California Ph.D. dissertation.

Byarushengo, Ernest, Larry M. Hyman \& Sarah Tenenbaum. 1976. Tone, accent and assertion in Haya. In Larry M. Hyman (ed.), Studies in Bantu tonology, 183-205. Los Angeles: Department of Linguistics, University of Southern California.

Cassimjee, Farida. 1998. Isixhosa tonology: an optimal domains theory analysis. Munich: LINCOM EUROPA.

Chebanne, Andy. 1992. The Setswana i(n) verbal prefix. Paper presented at the Annual Conference of African Linguistics 23, Michigan State University.

Cole, Desmond T. 1955. An introduction to Tswana grammar. Cape Town: Longman.

Contini-Morava, Ellen. 1983. Ranking of participants in Kinyarwanda: the limitations of arbitrariness in language. Anthropological Linguistics 25. 425-435. 
Creissels, Denis. 2002. Valence verbale et voix en Tswana. Bulletin de la Société de linguistique de Paris 97. 371-426.

Dalgish, Gerald. 1974. Arguments for a unified treatment of y-initial and vowel-initial roots in Olutsootso. Studies in the Linguistic Sciences 4. 76-90.

Dammann, Ernst. 1957. Studien zum Kwangali. Grammatik, texte, glossar. Hamburg: Cram, de Gruyter \& co.

Demuth, Katherine \& Mark Johnson. 1990. Interactions between discourse function and agreement in Setswana. Journal of African Languages and Linguistics 20. 41-61.

Devos, Maud \& Daniel Van Olmen. 2013. Describing and explaining the variation of Bantu imperatives and prohibitives. Studies in Language 37. 1-57.

Dickens, Patrick. 1984. The history of the so-called strengthening in Tswana. Journal of African Languages and Linguistics 6. 97-125.

Diercks, Michael \& Justine Sikuku. 2011. Object marking as pronominal incorporation in Lubukusu. Paper presented at the 4th International Conference on Bantu languages, Humboldt University of Berlin.

Downing, Laura J. 1994. SiSwati verbal reduplication and the theory of generalized alignment. Proceedings of the North East Linguistic Society 24. 81-95.

Downing, Laura J. 1996. The tonal phonology of Jita. Munich: LINCOM Europa.

Downing, Laura J. 1998a. On the prosodic misalignment of onsetless syllables. Natural Language and Linguistic Theory 16. 1-52.

Downing, Laura J. 1998b. Prosodic misalignment and reduplication. In Geert Booij \& Jaap van Marle (eds.) Yearbook of Morphology 1997, 83-120. Dordrecht: Kluwer Academic Publishers.

Downing, Laura J. 1999a. Verbal reduplication in three Bantu languages. In René Kager, Harry van der Hulst \& Wim Zonneveld (eds.), The prosody-morphology interface, 62-89. Cambridge: Cambridge University Press.

Downing, Laura J. 1999b. Morphological constraints on Bantu reduplication. Linguistic Analysis 29. 6-46.

Downing, Laura J. 1999c. Prosodic stem $\neq$ prosodic word in Bantu. In T. Alan Hall \& Ursula Kleinhenz (eds.), Studies on the phonological word, 73-98. Amsterdam: John Benjamins.

Downing, Laura J. 2000. Morphological and prosodic constraints on Kinande verbal reduplication. Phonology 17. 1-38.

Downing, Laura J. 2001. Ungeneralizable minimality in Ndebele. Studies in African Linguistics 30. 33-58.

Downing, Laura J. 2003. Compounding and tonal non-transfer in Bantu languages. Phonology 20. $1-42$.

Downing, Laura J. 2004. Bukusu reduplication. In Chege Githiora, Heather Littlefield \& Victor Manfredi (eds.), Trends in African Linguistics 5, 73-84. Lawrenceville, NJ: Africa World Press.

Downing, Laura J. 2005. On the ambiguous segmental status of nasals in homorganic NC sequences. In Marc van Oostendorp \& Jeroen van de Weijer (eds.), The internal organization of phonological segments, 183-216. Berlin: Mouton de Gruyter.

Downing, Laura J. 2006. Canonical forms in prosodic morphology. Oxford: Oxford University Press.

Downing, Laura J. 2009. Linear disorder in Bantu reduplication. Paper presented at the Workshop on the Division of Labor between Morphology and Phonology and Fourth Network Meeting, Meertens Instituut, Amsterdam.

Duranti, Alessandro. 1979. Object clitic pronouns in Bantu and the topicality hierarchy. Studies in African Linguistics 10. 31-45. 
Duranti, Alessandro \& Ernest Byarushengo. 1977. On the notion of 'direct object'. In Ernest Byarushengo, Alessandro Duranti \& Larry M. Hyman (eds.), Haya Grammatical Structure, 5471. Los Angeles, CA: Department of Linguistics, USC.

Ebarb, Kristopher, Michael R. Marlo, \& Peter Otiato. in prep. Nyala-West tonology. Bloomington, IN, Columbia, MO \& Lawrence, KS: Indiana University, University of Missouri \& University of Kansas unpublished ms.

Engelbrecht, Jan Anthonie. 1957. Notes on the imperative in Zulu. African Studies 16. 102-107.

Fivaz, Derek \& Sakaria Shikomba. 1986. A reference grammar of Oshindonga (Wambo). Windhoek: The Academy, Department of African Languages.

Haddon, Ernest. 1955. Note on the verbal -e stem in East African Bantu. Journal of the International African Institute 25: 79-83.

Halme, Riikka. 2004. A tonal grammar of Kwanyama. Cologne: Rüdiger Köppe Verlag.

Harjula, Lotta. 2004. The Ha language of Tanzania. Cologne: Rüdiger Köppe.

Hawkinson, Ann Katherine. 1986. Bakweri verb morphology. Berkeley, CA: University of California Ph.D. dissertation.

Hawkinson, Annie \& Larry M. Hyman. 1974. Hierarchies of natural topic in Shona. Studies in African Linguistics 5. 147-170.

Henderson, Brent. 2006. The syntax and typology of Bantu relative clauses. Urbana, IL: University of Illinois Ph.D. dissertation.

Herman, Rebecca. 1996. Prosodic structure in SiSwati. Ohio State University Working Papers in Linguistics 48. 31-55.

Hualde, José. 1989. Double object constructions in KiRimi. In Robert Botne \& Paul Newman (eds.), Current Approaches to African Linguistics 5, 179-189. Dordrecht: Foris Publications.

Hubbard, Kathleen. 1995. 'Prenasalized consonants' and syllable timing: evidence from Runyambo and Luganda. Phonology 12. 235-256.

Hulstaert, Gustaf. 1961/1965/1966. Grammaire du lomongo. Tervuren: Musée royal de l'Afrique centrale.

Hyman, Larry M. 1987. Prosodic domains in Kukuya. Natural Language and Linguistic Theory 5. 311-333.

Hyman, Larry M. 1992. Moraic mismatches in Bantu. Phonology 9. 255-265.

Hyman, Larry M. 1993. Conceptual issues in the comparative study of the Bantu verb stem. In Salikoko Mufwene \& Lioba Moshi (eds.), Topics in African linguistics, 3-34. Amsterdam and Philadelphia: John Benjamins.

Hyman, Larry M. 2001. On the limits of phonetic determinism in phonology: *NC revisited. In Beth Hume \& Keith Johnson (eds.), The role of speech perception in phonology, 141-185. New York: Academic Press.

Hyman, Larry M. 2003a. Segmental phonology. In Derek Nurse \& Gérard Philippson (eds.), The Bantu languages, 42-58. London: Routledge.

Hyman, Larry M. 2003b. Basaa A.43. In Derek Nurse \& Gérard Philippson (eds.), The Bantu languages, 257-282. London: Routledge.

Hyman, Larry M. 2007. Reconstructing the Proto-Bantu verbal unit. SOAS Working Papers in Linguistics 15. 201-211.

Hyman, Larry M. 2008. Directional asymmetries in the morphology and phonology of words, with special reference to Bantu. Linguistics 46. 309-350.

Hyman, Larry M. 2009. The natural history of verb-stem reduplication in Bantu. Morphology 19: 177-206.

Hyman, Larry M. 2011. The macro-Sudan belt and Niger-Congo reconstruction. Language Dynamics and Linguistic Change 1. 3-49. 
Hyman, Larry M. \& Edmond Biloa. 1992. Transparent low tone in Tuki. In Laura BuszardWelcher, Lionel Wee \& William Weigel (eds.), Proceedings of the Berkeley Linguistic Society 18, Special session on the typology of tone languages, 104-127. Berkeley, CA: Berkeley Linguistic Society.

Hyman, Larry M. \& Ernest Byarushengo. 1984. A model of Haya tonology. In George N. Clements \& John Goldsmith (eds.), Autosegmental studies in Bantu tone, 53-103. Dordrecht: Foris Publications.

Hyman, Larry M., Sharon Inkelas \& Galen Sibanda. 2008. Morpho-syntactic correspondence in Bantu reduplication. In Kristin Hanson \& Sharon Inkelas (eds.), The nature of the word: essays in honor of Paul Kiparsky, 273-310. Cambridge, MA: MIT Press.

Hyman, Larry M. \& Armindo Ngunga 1994. On the non-universality of tonal association conventions: evidence from Ciyao. Phonology 11. 25-68.

Itô, Junko \& Armin Mester. 1994. Reflections on CodaCond and Alignment. In Jason Merchant, Jaye Padgett \& Rachel Walker (eds.), Phonology at Santa Cruz, 27-46. Santa Cruz, CA: Linguistics Research Center, UC Santa Cruz.

Itô, Junko \& Armin Mester. 1999. Realignment. In René Kager, Harry van der Hulst \& Wim Zonneveld (eds.), The prosody-morphology interface, 188-217. Cambridge: Cambridge University Press.

Jones, Patrick. 2010. The phonological stem in Kinande verbal morphology. Cambridge, MA: Massachusetts Institute of Technology unpublished ms.

Julien, Marit. 2002. Syntactic heads and word formation. Oxford: Oxford University Press.

Kagaya, Ryohei. 1989. A study of the tonal system of the Mbaga dialect of the southern Pare language. In Ryohei Kagaya, Ruth Mfumbwa Besha \& Yasutoshi Yukawa (eds.), Studies in Tanzanian Languages, 95-204. Tokyo: ILCAA.

Kawahara, Shigeto. 2008. On the proper treatment of non-crisp-edges. In Mutsuko Endo Hudson, Peter Sells \& Sun-Ah Jun (eds.), Japanese/Korean Linguistics 13, 55-67. Stanford, CA: CSLI Publications.

Kearns, Lucie. 2008. Les marqueurs d'objet dans les langues bantoues et romanes. Montréal: Université du Québec à Montréal M.A. thesis.

Kidima, Lukowa. 1987. Object agreement and topicality hierarchies in Kiyaka. Studies in African Linguistics 18. 175-209.

Kidima, Lukowa. 1991. Tone and accent in Kiyaka. Los Angeles, CA: University of California $\mathrm{Ph} . \mathrm{D}$. dissertation.

Kisseberth, Charles W. 1981. Displaced tones in Digo (Part 2). Studies in the Linguistic Sciences 11. 73-120.

Kisseberth, Charles W. 1984. Digo tonology. In George N. Clements \& John Goldsmith (eds.), Autosegmental studies in Bantu tone, 105-182. Dordrecht: Foris Publications.

Kisseberth, Charles W. \& Mohammed I. Abasheikh. 2004. The Chimwiini lexicon exemplified. Tokyo: ILCAA.

Kuperus, Julianna \& Antoinette Mpunga wa Ilunga. 1990. Locative markers in Luba. Tervuren: Musée royal de l'Afrique centrale.

Lax, Michelle. 1996. The verbal system of Kigiryama. Madison, WI: University of Wisconsin Ph.D. dissertation.

Marlo, Michael R. 2002. Reduplication in Lusaamia. Indiana University Working Papers in Linguistics Online 2.

Marlo, Michael R. 2004. Prefixal reduplication in Lusaamia: evidence from morphology. In Proceedings of the 4th World Congress on African Linguistics, Akinbiyi Akinlabi \& Oluseye Adesola (eds.). Köln: Rüdiger Köppe. 
Marlo, Michael R. 2007. The verbal tonology of Lumarachi and Lunyala-West: two dialects of Luluyia (Bantu, J.30, Kenya). Ann Arbor, MI: University of Michigan Ph.D. dissertation.

Marlo, Michael R. 2008. Tura verbal tonology. Studies in African Linguistics 37. 153-243.

Marlo, Michael R. 2009. Khayo verbal tonology. Africana Linguistica XV. 77-129.

Marlo, Michael R. 2013. Verb tone in Bantu languages: micro-typological patterns and research methods. Africana Linguistica XIX. 137-234.

Marlo, Michael R. 2014. Morphosyntactic variation in Bantu object marking: Contributions of micro-comparative research to language documentation. Columbia, MO: University of Missouri unpublished ms.

Marlo, Michael R. to appear. On the number of object markers in Bantu languages. Journal of African Languages and Linguistics.

Marlo, Michael R., Leonard Chacha Mwita \& Mary Paster. 2014a. Problems in Kuria H tone assignment. Natural Language \& Linguistic Theory.

Marlo, Michael R., Leonard Chacha Mwita \& Mary Paster. 2014b. Kuria tone melodies. Africana Linguistica XX.

Marten, Lutz \& Nancy Kula. 2012. Object marking and morpho-syntactic variation in Bantu. Southern African Linguistics and Applied Language Studies 30. 237-253.

Marten, Lutz, Nancy Kula \& Nhlanhla Thwala. 2007. Parameters of morpho-syntactic variation in Bantu. Transactions of the Philological Society 105. 253-338.

Massamba, David. 1982. Aspects of accent and tone in Ci-Ruri. Bloomington, IN: Indiana University Ph.D. Dissertation.

Matondo, Masangu. 2003. Tone and prosodic morphology in Kisukuma. Los Angeles, CA: University of California Ph.D. dissertation.

Mchombo, Sam. 1993. On the binding of the reflexive and the reciprocal in Chichewa. In Sam Mchombo (ed.), Theoretical Aspects of Bantu Grammar, 181-207. Stanford, CA: CSLI Publications.

Mchombo, Sam. 2004. The syntax of Chichewa. Cambridge: Cambridge University Press.

Meeussen, A. E. 1959. Essai de grammaire rundi. Tervuren: Musée royal de l'Afrique central.

Meeussen, A. E. 1962. De tonen van subjunktief en imperatief in het Bantoe. Africana Linguistica I. 57-74.

Meeussen, A. E. 1967. Bantu grammatical reconstructions. Africana Linguistica III. 79-121.

Mmusi, Sheila. 1992. Obligatory contour principle effects and violations: the case of Setswana verbal tone. Urbana, IL: University of Illinois Ph.D. dissertation.

Morolong, Malillo \& Larry M. Hyman. 1977. Animacy, objects and clitics in Sesotho. Studies in African Linguistics 8. 199-218.

Mous, Maarten. 2003. The making of a mixed language: the case of Ma'a/Mbugu. Amsterdam: John Benjamins.

Muriungi, Peter. 2008. Phrasal movement inside Bantu verbs: deriving affix scope and order in Kintharaka. Tromsø: University of Tromsø Ph.D. dissertation.

Mutaka, Ngessimo. 1994. The lexical tonology of Kinande. Munich: LINCOM EUROPA.

Mutaka, Ngessimo \& Larry M. Hyman. 1990. Syllables and morpheme integrity in Kinande reduplication. Phonology 7. 73-119.

Mutonyi, Nasiombe. 2000. Aspects of Bukusu morphology and phonology. Columbus, OH: Ohio State University Ph.D. dissertation.

Mwansa, Joseph Mwenya. 2011. The acquisition of object markers by Bemba-speaking children. Leeds: University of Leeds Ph.D. dissertation.

Mwita, Chacha. 2008. Verbal tone in Kuria. Los Angeles, CA: University of California Ph.D. dissertation.

Myers, Scott. 1990. Tone and the structure of words in Shona. New York: Garland. 
Myers, Scott. 1998. AUX in Bantu morphology and phonology. In Larry M. Hyman \& Charles W. Kisseberth (eds.), Theoretical aspects of Bantu tone, 231-264. Stanford: CSLI Publications.

Nash, Jay. 1992. Aspects of Ruwund grammar. Urbana, IL: University of Illinois Ph.D. dissertation.

Ndayiragije, Juvénal. 2003. Théories linguistiques et réciprocité en Chichewa: la leçon du Kirundi. In Patrick Sauzet \& Anne Zribi-Hertz (eds.), Typologie des langues d'Afrique et universaux de la grammaire, Volume 1, 169-210. Paris: Harmattan.

Ngonyani, Deo. 2001. The morpho-syntax of negation in Kiswahili. Afrikanistische Arbeitspapiere 68. 17-33.

Nurse, Derek. 2007. Bantu tense and aspect systems. http://www.ucs.mun.ca/ dnurse/tabantu.html. Accessed 2 June 2013.

Nurse, Derek. 2008. Tense and aspect in Bantu. Oxford: Oxford University Press.

Nurse, Derek. n.d. Bajuni grammatical sketch. St. John's: Memorial University of Newfoundland unpublished ms.

Odden, David. 1987. Predicting tone in Kikuria. In David Odden (ed.), Current approaches to African linguistics 4, 311-326.

Odden, David. 1989. Predictable tone systems in Bantu. In Harry van der Hulst \& Norval Smith (eds.), Autosegmental studies on pitch accent systems, 225-251. Dordrecht: Foris Publications.

Odden, David. 1996. Patterns of reduplication in Kikerewe. Ohio State University Working Papers in Linguistics 48. 111-148.

Odden, David. to appear. Bantu phonology. Oxford Handbooks Online. Oxford: Oxford University Press.

Odden, David \& Mary Odden. 1985. Ordered reduplication in Kihehe. Linguistic Inquiry 16. 497 503.

Olson, Howard. 1964. The phonology and morphology of Rimi. Hartford, CT: Hartford Seminary Foundation.

Paulian, Christiane. 1975. Le kukuya: langue teke du Congo. Paris: SELAF.

Polak, Louise. 1983. Le réfléchi en bantou. Africana Linguistica IX. 270-304.

Polak, Louise. 1986. Les infixes ("préfixes objets") du bantu et leur reconstruction. Africana Linguistica X. 365-421.

Polak-Bynon, Louise. 1975. A Shi grammar. Tervuren, Belgium: Musée Royal de l'Afrique Centrale.

Poletto, Robert. 1998. Topics in Runyankore phonology. Columbus, OH: Ohio State University Ph.D. dissertation.

Riedel, Kristina. 2009. The syntax of object marking in Sambaa: a comparative Bantu perspective. Utrecht: LOT.

Rugemalira, Josephat M. 1991. What is a symmetrical language? Multiple object constructions in Bantu. In Proceedings of the Seventeenth Annual Meeting of the Berkeley Linguistics Society: Special Session on African Language Structures, 200-209.

Rugemalira, Josephat M. 1993. Bantu multiple "object" constructions. Linguistic Analysis 23: 226-252.

Rugemalira, Josephat M. 1997. The upper limit constraint on argument structures. In Robert Herbert (ed.), African linguistics at the crossroads: papers from Kwaluseni, 207-219. Koln: Rüdiger Köppe.

Rugemalira, Josephat M. 2005. A grammar of Runyambo. Dar es Salaam: Languages of Tanzania Project.

Schadeberg, Thilo. 1979. Über die töne der verbalen formen im Rimi. Afrika und Übersee 62: 288-313. 
Schlindwein, Deborah. 1986. On the invisibility of the first person singular object marker in KiRimi. Paper presented at Annual Conference on African Linguistics 17, Indiana University.

Sibanda, Galen. 2004. Verbal phonology and morphology of Ndebele. Berkeley, CA: University of California Ph.D. dissertation.

Sikuku, Justine M. 2012. Comparing reflexive and object marking in Lubukusu. Paper presented at World Congress of African Linguistics 7. Buea: University of Buea.

van der Spuy, Andrew. 1993. Dislocated noun phrases in Nguni. Lingua 90. 335-355.

Van Otterloo, Roger. 2011. The Kifuliiru language, volume 2: a descriptive grammar. Dallas, TX: SIL International.

Whiteley, Wilfred H. 1956. A practical introduction to Gusii. Nairobi: East African Literature Bureau.

Woolford, Ellen. 1999. Animacy hierarchy effects on object agreement. In Paul Kotey (ed.), New dimensions in African linguistics and languages, 203-216. Trenton, NJ: Africa World Press.

Woolford, Ellen. 2000. Agreement in disguise. In Vicki Carstens \& Frederick Parkinson (eds.), Advances in African linguistics, 103-117. Trenton, NJ: Africa World Press.

Woolford, Ellen. 2001. Conditions on object agreement in Ruwund (Bantu). In Elena Benedicto (ed.), Indigenous languages, 177-201. Amherst, MA: GLSA.

Yukawa, Yasutoshi. 1987a. A tonal study of Luvale verbs. In Yasutoshi Yukawa, Simooya Jerome Hachipola \& Ryohei Kagaya (eds.), Studies in Zambian languages, 1-34. Tokyo: ILCAA.

Yukawa, Yasutoshi. 1987b. A tonal study of Mwenyi verbs. In Yasutoshi Yukawa, Simooya Jerome Hachipola \& Ryohei Kagaya (eds.), Studies in Zambian languages, 35-72. Tokyo: ILCAA.

Yukawa, Yasutoshi. 1987c. A tonal study of Ila verbs. In Yasutoshi Yukawa, Simooya Jerome Hachipola \& Ryohei Kagaya (eds.), Studies in Zambian languages, 185-256. Tokyo: ILCAA.

Yukawa, Yasutoshi. 1989a. A tonological study of Machame verbs. In Ryohei Kagaya, Ruth Mfumbwa Besha \& Yasutoshi Yukawa (eds.), Studies in Tanzanian languages, 223-338. Tokyo: ILCAA.

Yukawa, Yasutoshi. 1989b. A tonological study of Sukuma verbs. In Ryohei Kagaya, Ruth Mfumbwa Besha \& Yasutoshi Yukawa (eds.), Studies in Tanzanian languages, 339-404. Tokyo: ILCAA.

Yukawa, Yasutoshi. 1989c. A tonological study of Nilamba verbs. In Ryohei Kagaya, Ruth Mfumbwa Besha \& Yasutoshi Yukawa (eds.), Studies in Tanzanian languages, 405-450. Tokyo: ILCAA.

Yukawa, Yasutoshi. 1989d. A tonological study of Nyaturu verbs. In Ryohei Kagaya, Ruth Mfumbwa Besha \& Yasutoshi Yukawa (eds.), Studies in Tanzanian languages, 451-480. Tokyo: ILCAA.

Yukawa, Yasutoshi. 1989e. A tonological study of Nyiha verbs. In Ryohei Kagaya, Ruth Mfumbwa Besha \& Yasutoshi Yukawa (eds.), Studies in Tanzanian languages, 481-518. Tokyo: ILCAA.

Yukawa, Yasutoshi. 1989f. A tonological study of Makonde verbs. In Ryohei Kagaya, Ruth Mfumbwa Besha \& Yasutoshi Yukawa (eds.), Studies in Tanzanian languages, 519-560. Tokyo: ILCAA.

Yukawa, Yasutoshi. 1992. A tonological study of Ngombe verbs. In Yasutoshi Yukawa, Ryohei Kagaya \& Shigeki Kaji (eds.), Studies in Cameroonian and Zairean languages, 269-302. Tokyo: ILCAA.

Zanuttini, Raffaella. 1997. Negation and clausal structure: a comparative study of Romance languages. New York \& Oxford: Oxford University Press.

Zerbian, Sabine. 2006. Expression of information structure in the Bantu language Northern Sotho. Berlin: Humboldt University Ph.D. dissertation. 
Zeller, Jochen. 2012. Object marking in Zulu. Southern African Linguistics and Applied Language Studies 30. 219-235.

Michael R. Marlo

University of Missouri marlom@missouri.edu
Received: 15 January 2013

Accepted: 15 July 2013

Revisions: 28 December 2014 